\title{
The Climate of the MIS-13 Interglacial according to HadCM3
}

\author{
Helene Muri,* André Berger, QiuZhen Yin, Mehdi Pasha Karami, \\ AND PIERRE-YVES BARRIAT \\ Earth and Life Institute, Georges Lemaître Centre for Earth and Climate Research, \\ Université Catholique de Louvain, Louvain-la-Neuve, Belgium
}

(Manuscript received 30 July 2012, in final form 11 July 2013)

\begin{abstract}
The climate of the Marine Isotopic Stage 13 (MIS-13) is explored in the fully coupled atmosphereocean general circulation model the Hadley Centre Coupled Model, version 3 (HadCM3). It is found that the strong insolation forcing at the time imposed a strengthened land-ocean thermal contrast, resulting in an intensified summer monsoon over Asia. The addition of land ice over North America and Eurasia results in a stationary wave feature across the Eurasian continent. This leads to a high pressure anomaly over the Sea of Japan with increased advection of warm moist air onto the Chinese landmasses. This in turn reinforces the East Asian summer monsoon (EASM), highlighting the counterintuitive notion that, depending on the background insolation and its size, ice can indeed contribute to strengthening the EASM. The modeling results support the geological record indication of a strong EASM 500000 years ago. Furthermore, Arctic Oscillation, El Niño-Southern Oscillation, and Indian Ocean dipole-like teleconnection features are discussed in the MIS-13 environment. It is shown that the change in the tropical Pacific sea surface temperature has the potential to impact the North Atlantic climate through an atmospheric "bridge."
\end{abstract}

\section{Introduction}

A fully coupled atmosphere-ocean general circulation model (AOGCM) is used to examine the climate of the Marine Isotopic Stage 13 (MIS-13), 500 000 years before present, with an emphasis on the Asian monsoon. This interglacial is of particular interest as it appears to have had unusually strong monsoons, according to some paleorecords. At the time, among the nine interglacials of the past 800000 years, MIS-13 had relatively low methane and carbon dioxide concentrations and was a cool interglacial, at least in Antarctica (Jouzel et al. 2007). Why such a strong monsoon could have occurred during a cold interglacial is still not fully understood.

The loess records indicate that China was both warmer and wetter during MIS-13 compared to today (Kukla

\footnotetext{
* Current affiliation: Meteorology and Oceanography Section, Department of Geosciences, University of Oslo, Oslo, Norway.

Corresponding author address: Helene Muri, University of Oslo, Department of Geosciences, Meteorology and Oceanography Section, Postboks 1022 Blindern, 0315 Oslo, Norway.

E-mail: helene.muri@geo.uio.no
}

et al. 1990; Guo et al. 1998, 2009). Sediment core data from the eastern Tibetan Plateau (Chen et al. 1999) and red soils from southern China (Yin and Guo 2006) lend support to the idea of stronger precipitation rates during MIS-13. This is also indicated in the $\delta^{18} \mathrm{O}$ records from speleothems in western China (Cheng et al. 2012). Evidence of a strong North African monsoon during MIS-13 is found from a thick layer of sapropel in a core from the Mediterranean Sea (Rossignol-Strick et al. 1998). Indications of positive rainfall anomalies at the time are also found in observations from the Amazon basin (Harris and Mix 1999). Ostracod data from England indicate that the local temperatures could have been similar to today, with a larger seasonality and possibly colder-or much colder-winters (Holmes et al. 2010). On the other hand, the Antarctic ice core records show that the MIS-13 was a cool interglacial, with Antarctic temperatures $1^{\circ}-1.5^{\circ} \mathrm{C}$ colder than during the last millennium (Jouzel et al. 2007).

De Vernal and Hillaire-Marcel (2008) investigated the pollen content in sediment cores from the Greenland coast, showing that herb and shrub (i.e., nonarboreal) pollen were abundant around $500 \mathrm{ka}$. Dinocyst data from the Greenland coast further show that the sea 
surface temperatures in that region were $\sim 2^{\circ} \mathrm{C}$ during winter and $\sim 4^{\circ} \mathrm{C}$ in summer (de Vernal and HillaireMarcel 2008), compared to around $3.9^{\circ}$ and $7.3^{\circ} \mathrm{C}$, respectively, at present (Locarnini et al. 2006). Pollen data can give indications of the extent of the Greenland Ice Sheet, in the sense that vegetation abundance implies a larger area of ice free conditions. Based on this assumption, the pollen data of de Vernal and HillaireMarcel suggest that the Greenland Ice Sheet most likely was substantially reduced during MIS-13. Spahni et al. (2005) speculated that the MIS-13 Northern Hemisphere (NH) ice sheets could have had a more southerly extension compared to previous interglacials owing to its relative coolness, however. According to data from Lake Baikal, on the other hand, there was seemingly a lack of extensive mountain glaciations from MIS-15 to MIS-11 (Prokopenko et al. 2002).

Considering the myriad of somewhat-mixed-signal paleodata for the MIS-13 climate, GCM experiments are needed to further our knowledge and understanding of this interglacial.

In this work, the possible existence of a positive Arctic Oscillation (AO)-like climate coupled to a positive Indian Ocean dipole (IOD)-like state is suggested in the MIS-13 mean climate. The positive phase of the Arctic Oscillation is characterized by the deepening of sea level pressure over the North Pole and a heightening at the midlatitudes (Thompson and Wallace 2000). This directs the oceanic storm tracks farther north and typically advects warmer and moister air zonally onto the continents. El Niño-Southern Oscillation (ENSO) involves numerous changes to the atmospheric and oceanic state, including anomalously warm waters in the equatorial east Pacific (e.g., Trenberth and Paolino 1981). This facilitates enhanced convective activity, which tends to reverse the trade winds, and a reorganization of the Hadley and Walker cells ensues (Trenberth et al. 1998). The changes to the upper-level winds have the potential to trigger Rossby waves, which transport the El Niño signal to higher latitudes (Hoskins and Jin 1991). ENSO can affect the SSTs of the Indian Ocean and lead to socalled Indian Ocean dipole events. The positive IOD phase consists of a region of negative SST anomaly to the east of a positive anomaly in the tropical Indian Ocean (Yamagata et al. 2003). AO, ENSO, and IOD events have the potential to impact the monsoons of India and East Asia.

The monsoons arise from differential heating between land and ocean. When the landmasses warm up in springsummer, the land-sea temperature gradient is increased, which sets up an onshore low-level wind. A low pressure center develops over land with an anticyclonic outflow aloft. A high pressure center over the ocean drives the surface winds toward the land. This onshore moisture flux feeds the resulting strong monsoonal precipitation. This circulation pattern is reversed in winter. The East Asian summer monsoon (EASM) is not only affected by El Niño-Southern Oscillation and the Indian Ocean dipole, but a number of other factors including, for example, the state of the intertropical convergence zone (ITCZ), the sea surface temperatures of the west Pacific warm pool, the Eurasian land surface properties, and the North Pacific high pressure cell (Lau et al. 2000). Extratropical dynamics and tropical thermodynamics affect the jet stream over Asia, which is a governing factor for the placement of the monsoon front (Sampe and Xie 2010). A substantial contribution of the monsoon rainfall is supplied by the mei-yu, baiu, and changma fronts (Chen 1983) - referred to as the rainy seasons over the land regions of China, Japan, and Korea, respectively. They can be viewed as one large-scale front, but they are not necessarily active at the same time, as the monsoon front progresses northward and then retreats on a time scale of around May-September. The mei-yu system provides precipitation to a large part of China. The front emerges in late April and peaks in intensity in mid-June. It develops from the collision of warm and moist air masses of the Pacific subtropical high to the south and the cooler and drier air of a migrating high pressure cell to the north (Chen 1983). The baiu season in Japan usually lasts from June to mid-July and tends to be less intense than the mei-yu. The baiu front results from the interaction of cold northerly airflow and warm moist southerlies, advected northward by the western branch of the North Pacific high. This creates unstable convective air masses over the Japanese archipelago (Sampe and Xie 2010). The changma front supplies rainfall to Korea, as it runs at a right angle to the peninsula, stretching from the northwest Pacific to the west side of the Tibetan Plateau (Oh et al. 2007).

The MIS-13 climate was first inspected with a climate model in the work of Yin et al. (2008). The LochVecode-Ecbilt-Clio-Agism Model (LOVECLIM), an earth system model of intermediate complexity (EMIC), was used to evaluate the response to the astronomical greenhouse gas (GHG) and ice sheet forcings of MIS-13. It was revealed that the strong insolation forcing led to stronger NH monsoons. The inclusion of ice sheets in the NH further enhanced the East Asian summer monsoon, due to a "wave train" across Eurasia. Yin et al. (2008) identified the need to confirm these findings with a fully coupled GCM, owing to the relative simplicity of the LOVECLIM three-level atmosphere, using prescribed cloud cover. It is also essential to check the model dependency of the results. The AGCM results of Muri et al. (2011) gave further insight into the MIS-13 
TABLE 1. The astronomical parameters and GHG concentrations for the preindustrial (PI) and MIS-13 experiments.

\begin{tabular}{lcccccc}
\hline \hline & Obliquity & Eccentricity & Perihelion (lon) & $\mathrm{CH}_{4}(\mathrm{ppb})$ & $\mathrm{CO}_{2}(\mathrm{ppm})$ & $\mathrm{N}_{2} 0(\mathrm{ppb})$ \\
\hline PI & $23.446^{\circ}$ & 0.016724 & $102.04^{\circ}$ & 760 & 280 & 270 \\
MIS-13 & $23.377^{\circ}$ & 0.034046 & $274.05^{\circ}$ & 510 & 240 & 280 \\
\hline
\end{tabular}

climate, though those AGCM simulations used prescribed SSTs from the LOVECLIM experiments of Yin et al. (2008). The experiments performed in this work are independent of any previous MIS-13 modeling and are also the first more complex AOGCM experiments of MIS-13. Herein we investigate if and how it is possible to have stronger monsoons during MIS-13 under the influence of insolation and greenhouse gases and of additional Northern Hemisphere ice sheets. Although the MIS-13 ice sheet configuration is uncertain, the assumptions of Yin et al. (2008) are followed, as the $\delta^{18} \mathrm{O}$ of benthic foraminifera from marine sediment cores indicate a larger ice volume. Land ice was therefore added to North America and west Eurasia in the model for sensitivity studies.

This paper evaluates the impacts of insolation, greenhouse gases, and ice sheets on the MIS-13 climate, including the East Asian summer monsoon. The findings of Yin et al. (2008) with regards to a strengthened EASM for MIS-13 with further ice sheet reinforcement, are corroborated by the results of this study. Furthermore, the GCM results are compared to geological records to the extent possible. The model and experiments are described in section 2. The impacts of insolation and GHG on the MIS-13 climate are investigated in section 3a. Teleconnection patterns in a MIS-13 setting are explored in sections $3 \mathrm{~b}-3 \mathrm{~d}$. Section 4 evaluates the impacts of additional North American and Eurasian ice sheets on the MIS-13 climate, in particular on the East Asian monsoon. It is followed by a summary and conclusions (section 5).

\section{The HadCM3 model and experimental design}

The Hadley Centre Coupled Model, version 3 (HadCM3), is a climate configuration of the Met Office Unified Model. It is a fully coupled AOGCM and is widely used, including in the Intergovernmental Panel on Climate Change (IPCC) Third and Fourth Assessment Reports. The atmosphere has 19 vertical levels and a time step of $30 \mathrm{~min}$. The longitude by latitude resolution is $3.75^{\circ} \times 2.5^{\circ}$ (Pope et al. 2000). The atmosphere is based on the hydrostatic and primitive equations and uses hybrid coordinates in the vertical. Essential physical processes including clouds, radiation, convection, and precipitation are parameterized. The surface albedo in the land surface scheme [Met Office Surface Exchange Scheme, version 2.1 (MOSES 2.1); Cox et al. (1999)] is a function of snow depth, vegetation type, and temperature of snow and ice. The orography and gravity wave parameterization includes the effects of flow blocking, trapped lee waves, and high drag states (Gregory et al. 1998).

The HadCM3 ocean has 20 vertical levels with a $1.25^{\circ}$ latitude $\times 1.25^{\circ}$ longitude Arakawa B grid (Gordon et al. 2000). It is based on the primitive equations, and the time step is $1 \mathrm{~h}$. A thermodynamic sea ice model with leads and snow cover is included in the ocean. The atmosphere and ocean are coupled once a day. The atmosphere uses fixed SST throughout the day and then passes the accumulated fluxes of heat, moisture, and momentum to the ocean model, which then carries forward the integration. More details of the model are found in Pope et al. (2000) and Gordon et al. (2000).

The internal variability of the HadCM3 model is documented in Collins et al. (2001). The model has representative ENSO and Arctic Oscillation variability, broadly similar to observations. The Arctic Oscillation in HadCM3 is also assessed in Gillett et al. (2002). Spencer et al. (2005) evaluated the IOD in HadCM3 and found the representation to be realistic.

Three model experiments performed with HadCM3 are

1) the preindustrial (PI), year 1850, control run;

2) the MIS-13 no-ice with the astronomical parameters and GHG values set to those of the 506-ka (Table 1) modern land ice distribution;

3) the MIS-13 ice with 506-ka astronomical parameters and GHGs as in experiment 2 and including additional ice sheets over North America and western Eurasia [see Fig. 2 in Muri et al. (2011)].

The boundary conditions in the two MIS-13 runs were changed according to Yin et al. (2008), whereupon the astronomical configuration was set to those of $506 \mathrm{ka}$ (Berger 1978). This involves changing the obliquity (the axial tilt) of Earth, the eccentricity of its orbit around the sun, and the longitude of perihelion (Table 1). Today perihelion occurs around the $\mathrm{NH}$ winter solstice. At $506 \mathrm{ka}$, on the other hand, the closest approach to the sun was during NH summer. These new parameter values lead to changes in the incoming solar radiation at the top of the atmosphere (insolation) in the model. Modern 


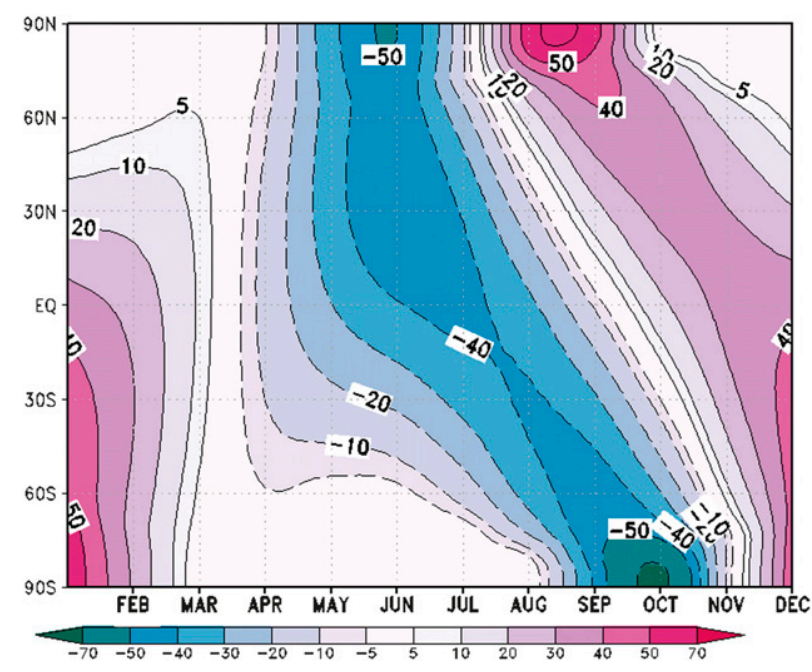

FIG. 1. The differences in insolation $\left(\mathrm{W} \mathrm{m}^{-2}\right.$; incoming solar radiation at the top of the atmosphere) between the MIS-13 and control simulations.

values were used in the control simulation for obliquity, eccentricity, and longitude of perihelion. The differences in MIS-13 insolation compared to present are shown in Fig. 1. Earth received more energy during boreal summer and less during winter at $506 \mathrm{ka}$ than presently. The greenhouse gas concentrations were altered (cf. Table 1), and the largest radiative forcing from the GHG changes is from the $\mathrm{CO}_{2}$ reduction, $-0.79 \mathrm{~W} \mathrm{~m}^{-2}$. The volume of the ice sheet added to North America is of $7.38 \mathrm{~km}^{3}$, that is, twice the size of the west Eurasian one of $3.63 \mathrm{~km}^{3}$.

The last 100 years of the model runs were used in the analysis. The model experiments had reached equilibrium in the surface climate after a long spinup of 700 years. Importantly, the surface climate is stable, with no statistically significant trends on multicentury time scales. The data were tested using linear regression and a Student's $t$ test, with a $p$ value of 0.05 . There is a nonsignificant trend in the ocean surface temperatures of the MIS-13 experiments of $-0.006 \mathrm{~K}_{\text {century }}{ }^{-1}$ and a slow linear trend in the deep ocean of $-0.06 \mathrm{~K}$ century $^{-1}$ at $3347 \mathrm{~m}$. This is comparatively small considering the size of the forcing changes in the model from the applied boundary conditions and should not affect the conclusions of this study.

\section{The MIS-13 climate}

\section{a. Model climatology and comparison to geological reconstructions}

First, the Marine Isotopic Stage 13 no-ice experiment is compared to the preindustrial experiment. The GHG and insolation are changed in this MIS-13 experiment (Table 1, Fig. 1). The June-August (JJA) air temperature at $1.5 \mathrm{~m}$ reveals a strong warming of the continents during MIS- 13 of as much as $3^{\circ}-5^{\circ} \mathrm{C}$ across the extratropics (Fig. 2a). This continental heating is also seen in the LOVECLIM (Yin et al. 2008) and the Action de Recherche Petite Echelle Grande Echelle (ARPEGE) models (Muri et al. 2011). The lack of substantial mountain glaciation during MIS-13, suggested by Prokopenko et al. (2002), could have been caused by this prominent JJA warming of the Eurasian continent with a modeled $3^{\circ}-7^{\circ} \mathrm{C}$ warming in the Baikal region. A cooling of $1^{\circ}-$ $3^{\circ} \mathrm{C}$ is seen over India and tropical North Africa where there is a strong increase in the monsoon precipitation. Furthermore, there is a cooling of $3^{\circ}-5^{\circ} \mathrm{C}$ across the Southern Ocean due to the summer remnant effect of insolation and a reduction in the $\mathrm{CO}_{2}$ concentrations of $40 \mathrm{ppm}$ (Yin and Berger 2012). There is also a $2^{\circ}-3^{\circ} \mathrm{C}$ cooling over Antarctica. The Antarctic, indeed, experiences cooler conditions throughout the year, endorsing the suggestion of a cooler MIS-13 from the ice core records from Dome C (Spahni et al. 2005). The DecemberFebruary (DJF) temperatures reveal a MIS-13 cooling everywhere, particularly at high latitudes where the magnitudes are of $3^{\circ}-7^{\circ} \mathrm{C}$ (Fig. $2 \mathrm{~b}$ ), as a response to lower $\mathrm{CO}_{2}$ concentrations and Northern Hemisphere winter occurring at aphelion.

The MIS-13 no-ice global-mean JJA temperatures are of the same magnitude as the PI, though the annualmean and winter temperatures are $1^{\circ}-2^{\circ} \mathrm{C}$ colder. Thus, a larger seasonality is seen in the model, as one might expect from Fig. 1. A larger amplitude in the seasonal cycle at MIS-13 has indeed been suggested by Holmes et al. (2010). Ostracod and herptile data from the English Channel were used to investigate the temperatures of MIS-13. The data show indications of local winter temperatures being cooler than presently, while the summer temperatures were similar to today. The MIS-13 no-ice simulation shows no significant changes in JJA temperatures over Britain and the channel (Fig. 2a) and $1^{\circ}-2^{\circ} \mathrm{C}$ cold anomaly during DJF (Fig. $2 b$ ), hence substantiating the findings of Holmes et al. (2010).

The JJA precipitation rate differences show a northward shift in the ITCZ across the Atlantic (Fig. 2c). The Central American monsoon is wetter, as well as the North African, Indian, and East Asian monsoons. The model results thus support the paleoindices from Kukla et al. (1990), Rossignol-Strick et al. (1998), Guo et al. (1998), and Yin and Guo (2006) of wetter conditions in these monsoon areas. The sapropel data from a marine core in the eastern Mediterranean show a substantial peak in the monsoon index at $506 \mathrm{ka}$ (Rossignol-Strick et al. 1998). The origin of the sapropel is thought to be 

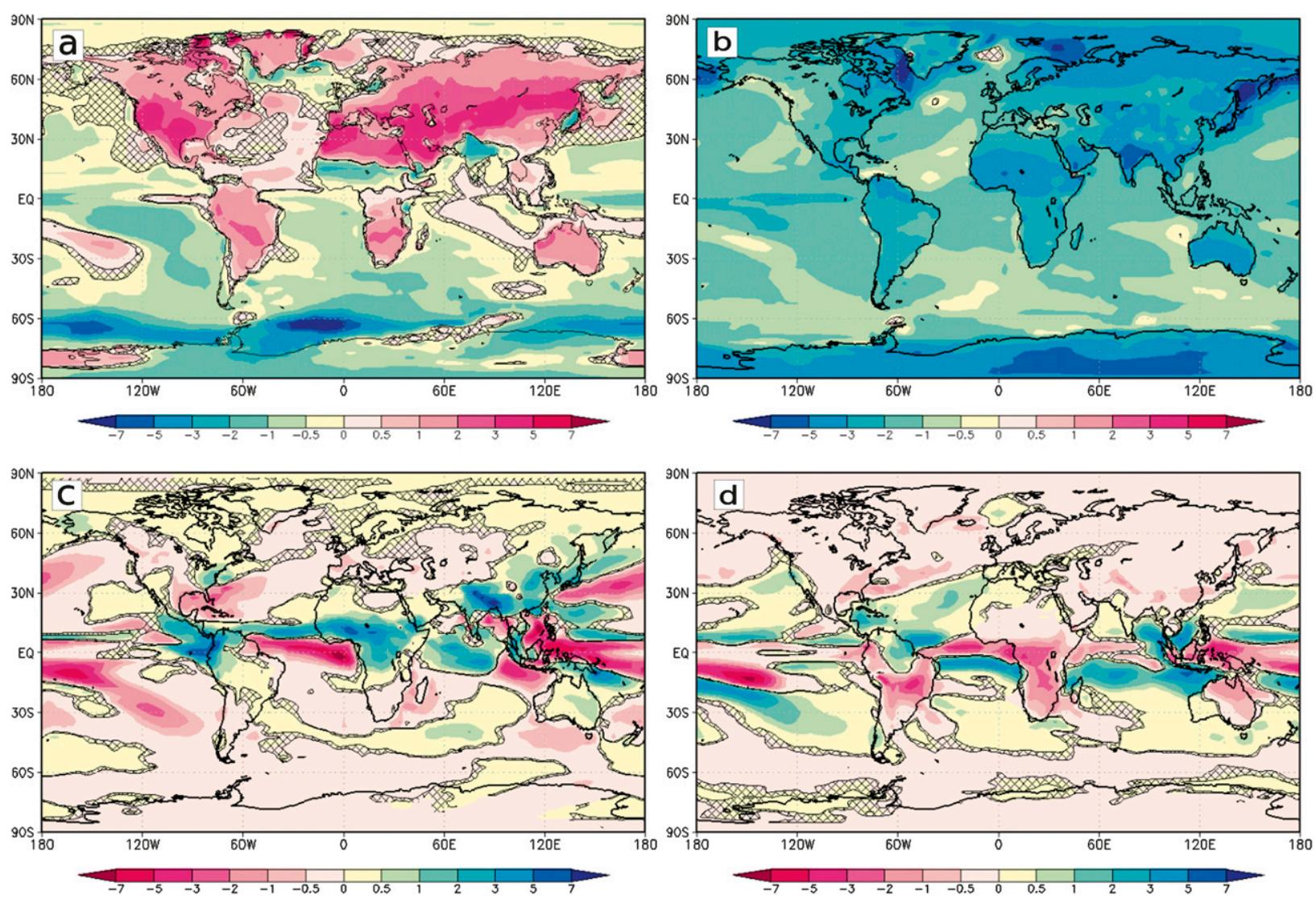

FIG. 2. Differences between the HadCM3 MIS-13 no-ice and PI experiments: $1.5-\mathrm{m}$ temperature (K) for (a) JJA and (b) DJF, and precipitation rate $\left(\mathrm{mm} \mathrm{day}^{-1}\right)$ for (c) JJA and (d) DJF. The areas outside of the black hatching indicate regions with a level of confidence higher than $95 \%$

from the Nile flood plains across Ethiopia, resulting from strong summer precipitation, indicative of a strong African monsoon. The model shows a significant increase in the JJA precipitation rates at MIS-13 across tropical Africa, including Ethiopia, corroborating the paleodata of Rossignol-Strick et al. (1998).

Guo et al. (1998) investigated the paleosoils in China on the Loess Plateau around $\sim 35^{\circ} \mathrm{N}, 110^{\circ} \mathrm{W}$ and found that MIS-13 likely was a period of great warmth and humidity, with strong seasonal contrasts. The well-developed soils from MIS-13 are thought to indicate a strong monsoon regime. The MIS-13 no-ice simulation supports the loess records, showing intensified monsoon activity, with stronger seasonality and warm, wet summers (Fig. 2). The JJA temperatures are modeled to be as much as $3^{\circ}-5^{\circ} \mathrm{C}$ warmer in that region. Furthermore, evidence of an enhanced EASM has been found in the paleosoils in southern China (Yin and Guo 2006), which is also found in the model.

The summer monsoon is actually modeled to be stronger and covering the whole of China with magnitudes of $0.5-5 \mathrm{~mm} \mathrm{day}^{-1}$ in excess compared to the PI (Fig. 2c).
The MIS-13 EASM enhancement is not only in agreement with the geological records, as described in the above paragraph, but also with EMIC (Yin et al. 2008) and AGCM results (Muri et al. 2011). The HadCM3 MIS-13 precipitation increase over central China is of comparable magnitude to the ones seen in LOVECLIM, that is, of $1-3 \mathrm{~mm} \mathrm{day}^{-1}$ ). The driver behind the monsoon strengthening is the increase in insolation due to the astronomical configuration at the time. The insolation increase is as much as $45-50 \mathrm{~W} \mathrm{~m}^{-2}$ north of $10^{\circ} \mathrm{N}$ in June (Fig. 1). The intense JJA heating of the NH continents increases the land-sea thermal contrast, reinforcing the onshore flux of moisture. The monsoon feeds off this moisture source and is, hence, strengthened at $506 \mathrm{ka}$.

The South American DJF monsoon is enhanced in the MIS-13 experiments, endorsing the paleo-observations of wetter conditions from the Amazon basin (Harris and Mix 1999). The terrigenous sediments from the Ceara Rise off the Brazilian coast mainly originate from the Amazon lowlands, having been transported by the Amazon River. It is thought that the sediment data 
reflect the north-south meandering of the intertropical convergence zone, following the glacial-interglacial stages. The high level of geothite found in the sediment dated to MIS-13 is thought to represent high precipitation and soil carbon levels in the Amazon lowlands. This precipitation is mainly delivered by the South American monsoon. There is a DJF increase in precipitation of $0.5-3.0 \mathrm{~mm} \mathrm{day}^{-1}$ over the Amazon lowlands in the MIS-13 no-ice model, as seen in Fig. 2d, the model hence lends support to the data of Harris and Mix (1999).

With regards to sea ice, there is an increase in the northward extent and amount in the Southern Ocean throughout the whole year. During DJF the Arctic sea ice rim extends farther south in the North Pacific, reaching western parts as far as north as Japan (Fig. 3a). In the North Atlantic, there is also an increase along the western edge from Newfoundland to Iceland and also in the Barents Sea. There is a decrease of sea ice concentration in the Norwegian Sea-however, a characteristic also seen in the LOVECLIM ocean (Yin et al. 2008; Sundaram et al. 2012). This North Atlantic feature persists through to the summer (Fig. 3b). An increase in salinity is also seen in the regions of increased sea ice concentrations (Fig. 3c). The salinity is reduced in the Mediterranean, tropical/subtropical North Atlantic, and the northern Indian Ocean; a freshening that is due to the increased rainfall rates. The lower salinity of the northern Indian Ocean is in agreement with the findings of Bassinot et al. (1994). The model simulates -0.5 to -2.0 -psu freshening of the water. The exact magnitude of change from the $\delta^{18} \mathrm{O}$ record in the marine sediment core from the Maldives is not known, but the sign of change is consistent between the data and model.

The JJA ocean surface streamfunction shows an increase in the Gulf Stream of $\sim 0.2$ sverdrups $(\mathrm{Sv} \equiv$ $10^{6} \mathrm{~m}^{3} \mathrm{~s}^{-1}$ ) along the East Coast of the United States (Fig. 3d) during the MIS-13. There is also an increase in the northward transport of the Kuroshio and an intensification of the North Pacific gyre, possibly due to the stronger overlying atmospheric anticyclone, associated with the Arctic Oscillation, as addressed in section $3 b$. With regards to the Southern Ocean, there is a yearround streamfunction decrease of $1-2 \mathrm{~Sv}$ south of $\sim 60^{\circ} \mathrm{S}$ and an increase of $0.2-1 \mathrm{~Sv}$ north of this. This shift results from the northward extension of the MIS-13 sea ice.

The DJF SSTs (Fig. 3e) show a cooling of most of the ocean of $0.5^{\circ}-4^{\circ} \mathrm{C}$. There are, however, two regions of positive anomalies in the North Atlantic at $\sim 50^{\circ} \mathrm{N}$ and in the Greenland Sea. This could be due to the presence of the AO-like ocean signal. The JJA SST exhibits a more complicated picture (Fig. 3f): there is still the large-scale cooling, as seen in DJF, except for the North Atlantic, Mediterranean, western Indian Ocean, and the South Pacific convergence zone. Furthermore, there is a positive anomaly along the equatorial far eastern Pacific. These JJA SST features are associated with the Arctic Oscillation and Indian Ocean dipole conditions, and "El Niño like" pattern, as discussed in subsequent sections $3 \mathrm{~b}-\mathrm{d}$.

Dinocyst assemblages from an ocean sediment core at $58^{\circ} \mathrm{N}, 48.2^{\circ} \mathrm{W}$ indicate a $1^{\circ} \mathrm{C}$ reduction in winter sea surface temperature at $506 \mathrm{ka}$ (de Vernal and HillaireMarcel 2008). The DJF SSTs off the southern coast of Greenland in the MIS- 13 no-ice experiment are $1^{\circ}-2^{\circ} \mathrm{C}$ colder (Fig. 3e). The modeled regional DJF SSTs are therefore consistent with this dataset, both in sign of change and magnitude.

\section{b. The Arctic Oscillation}

The JJA geopotential height at $700 \mathrm{mb}$ is higher at $\sim 35^{\circ}-40^{\circ} \mathrm{N}$ over the Pacific and Atlantic and lower north of $\sim 60^{\circ} \mathrm{N}$ (Fig. $4 \mathrm{a}$ ). The pattern of a positive anomaly to the south and negative at high latitudes is typical of the positive phase of the Arctic Oscillation. This oscillation is attributed to midlatitudinal internal atmospheric dynamics and impacts the mid to high latitudes. The AO positive phase is due to a stronger polar vortex. The AO is also linked to the strength and location of the extratropical jet (Ambaum et al. 2001). Thompson and Wallace (2000) showed that the AO can exist in all seasons, but a linkage between the troposphere and stratosphere is only present during DJF. The AO is closely related to the North Atlantic Oscillation (NAO) (Walker and Bliss 1932; Ambaum et al. 2001). It can be viewed as a regional version of the $\mathrm{AO}$, being confined to the Atlantic and not the additional Pacific basin (Hurrel 1995; Wallace 2000).

In the MIS-13 no-ice experiment, the pressure is lower over the pole and higher over the two ocean basins (Fig. 4a), which resembles a positive AO (e.g., Wallace 2000; Hurrel 1995). This is related to the increase in the ocean surface streamfunction mentioned above, that is, a stronger wind-driven circulation of the western boundary currents. The negative JJA air temperature and SST anomaly seen in the North Atlantic centered on $60^{\circ} \mathrm{N}$ (Fig. 3f) is due to the stronger north-northwesterly winds coming off the Greenland Ice Sheet (Fig. 4b), which also happens in the positive state of the Arctic Oscillation. The JJA increase in the Labrador Sea ice concentrations (Fig. 3b) is another representative feature of an AO positive phase. The drier conditions in the Mediterranean region and wetter in northeastern America are further typical characteristics of a positive AO (Hurrell and van Loon 1997). There is an increase 
(a)

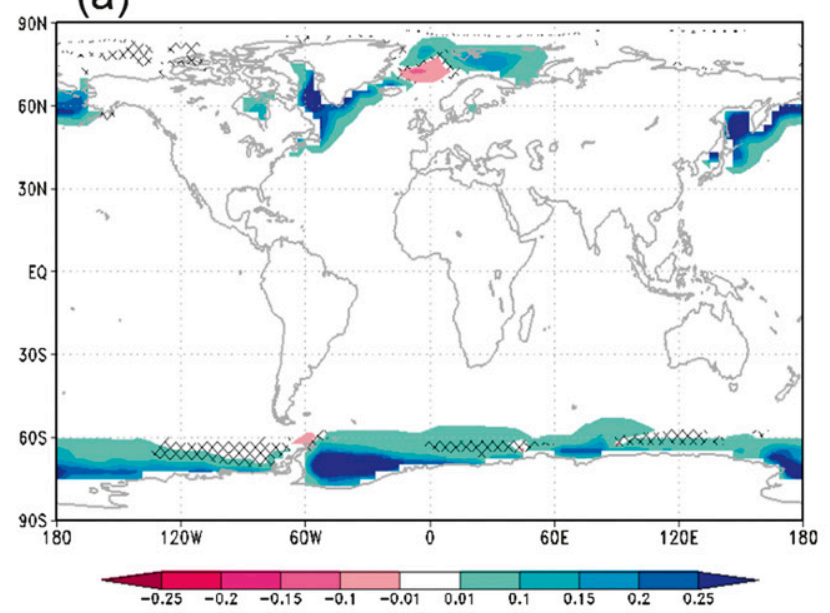

(c)

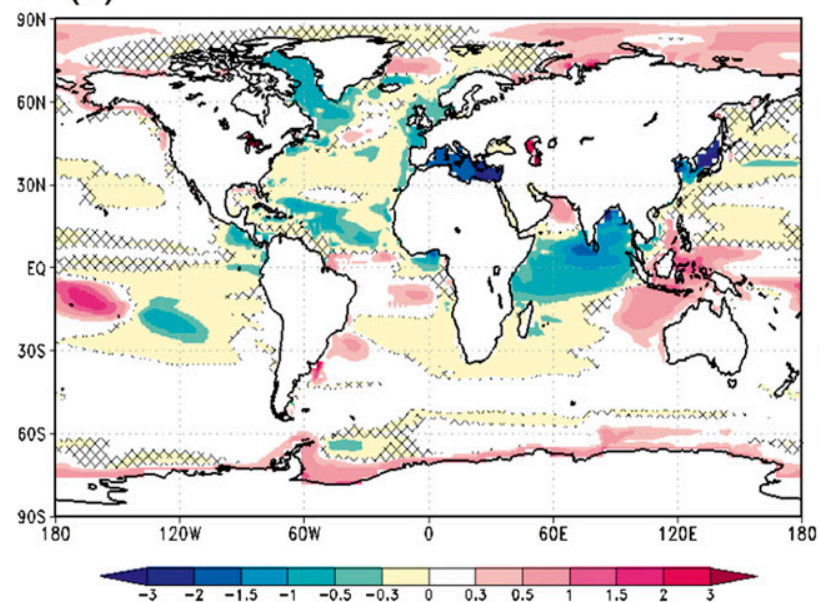

(e)

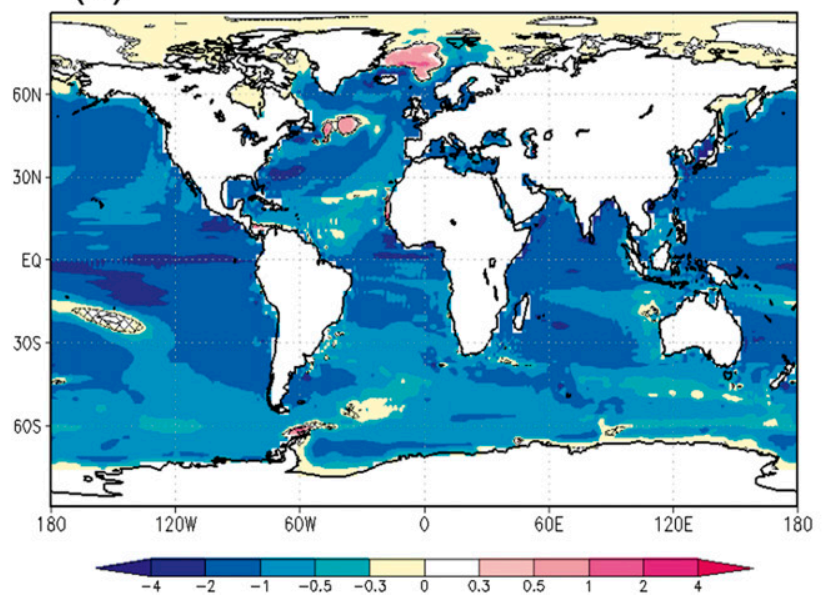

(b)

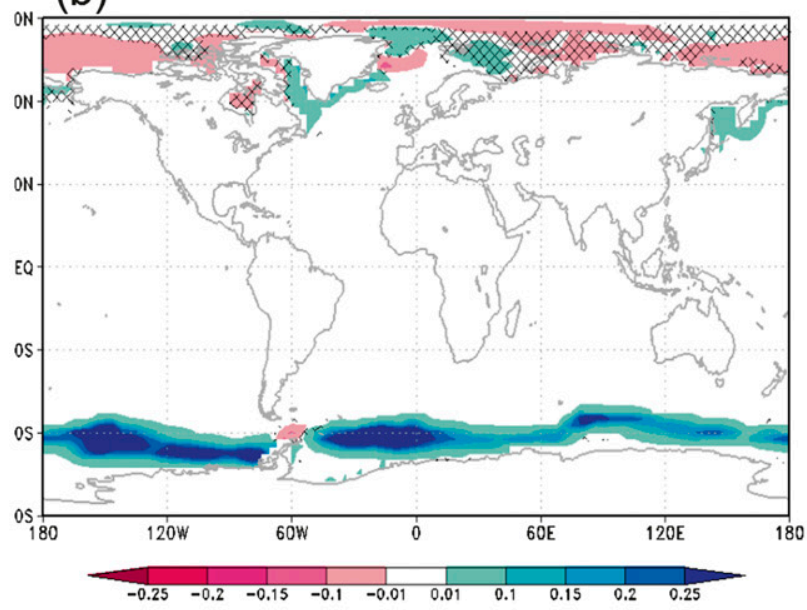

(d)

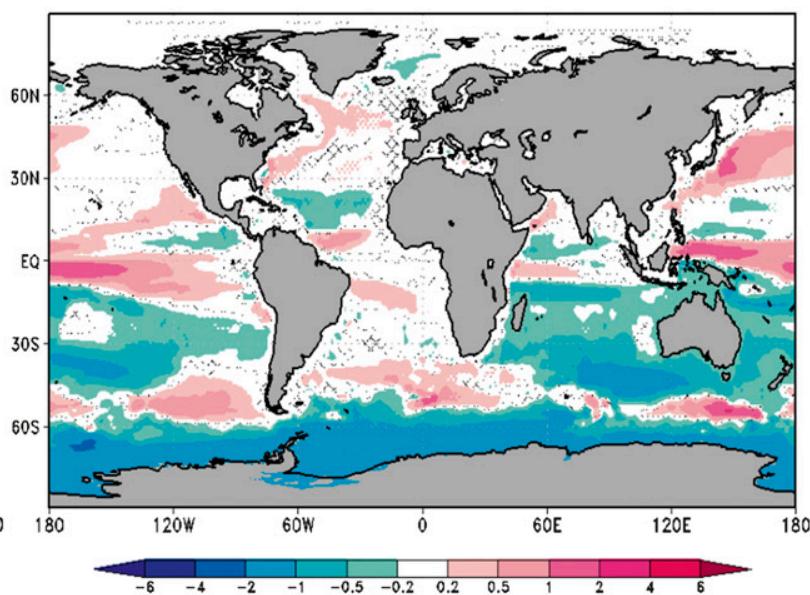

(f)

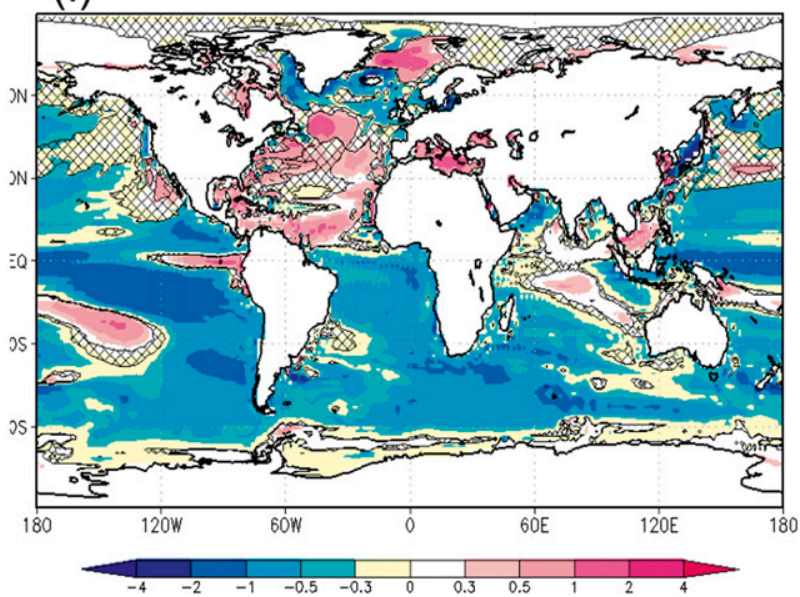

FIG. 3. Differences between the HadCM3 MIS-13 no-ice and PI experiments: sea ice concentration (fraction) for (a) DJF and (b) JJA; (c) the annual-mean salinity differences (psu), and (d) JJA ocean surface streamfunction $\left(\mathrm{cm}^{3} \mathrm{~s}^{-1}\right.$ ); (e) the DJF and (f) the JJA SST differences (K). Regions outside of the black hatching indicate a level of confidence higher than $95 \%$. 
(a)

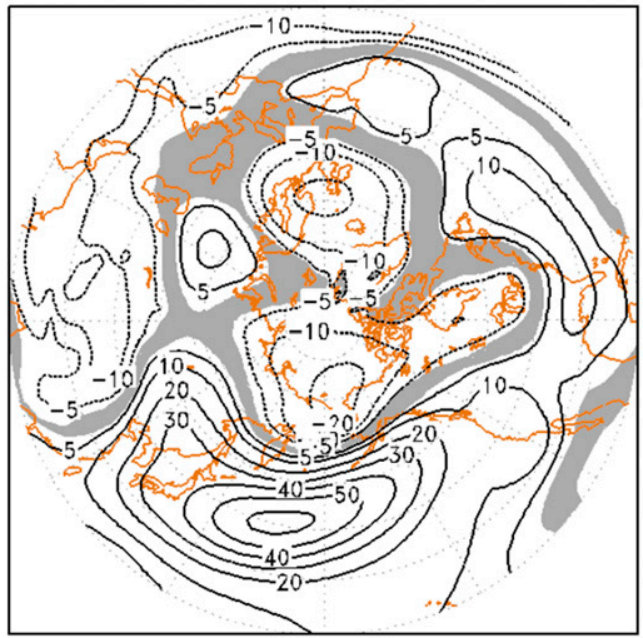

(b)

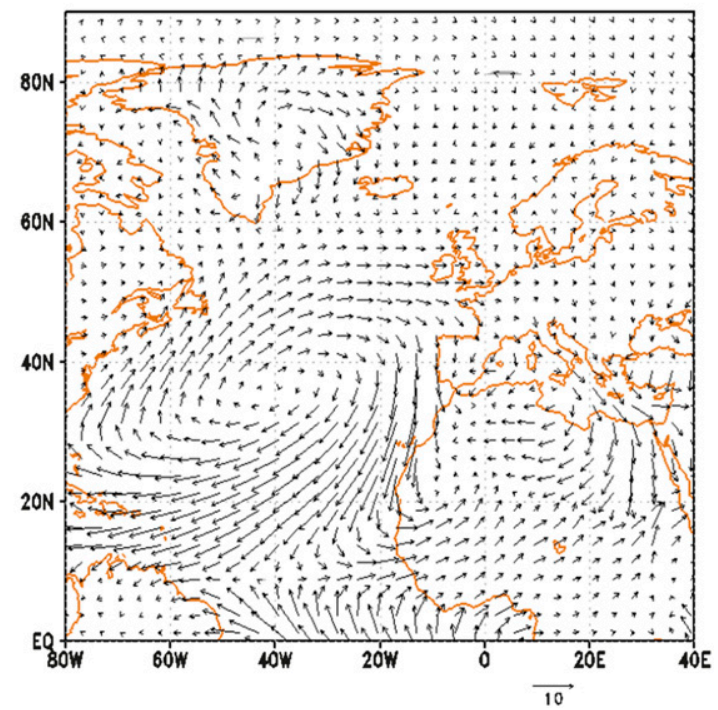

FIG. 4. (a) The JJA geopotential height differences (m) at $700 \mathrm{hPa}$ north of $20^{\circ} \mathrm{N}$ between the MIS- 13 no-ice and PI experiments; (b) the JJA MIS-13 no-ice surface winds $\left(\mathrm{m} \mathrm{s}^{-1}\right)$ in the North Atlantic. Regions outside of the gray shading indicate level of confidence higher than $95 \%$.

in the correlation between the AO index and drying in these areas in the MIS-13 no-ice climate compared to the preindustrial (Figs. 5a,b).

\section{c. El Niño-Southern Oscillation}

El Niño-Southern Oscillation and the Indian Ocean dipole (section 3d) are features of interannual variability. Here we deal only with the average summer climate calculated over the last 100 years of the simulation and refer to its characteristics as El Niño like and positive or negative "IOD like" (as done for positive or negative $\mathrm{AO}$ in the previous section).

With regards to the mean state in the tropical Pacific, the east-west temperature gradient in the sea surface temperatures of the tropical Pacific decreases in summer; hence, we refer to it as an El Niño-like pattern in the summer SSTs. This is while the winter and annual tropical Pacific SST are more La Niña-like with a cold anomaly core in the central Pacific. There is a $0.2^{\circ}-2^{\circ} \mathrm{C}$ warm anomaly in eastern parts, in the region $120^{\circ}-80^{\circ} \mathrm{W}$ (Fig. 6a), and $1^{\circ}-2^{\circ} \mathrm{C}$ cold anomaly along the equator in the western Pacific and hence a reduction in the east-west equatorial temperature gradient. This happens only during $\mathrm{NH}$ summer, and the annual mean and winter SSTs in the tropical Pacific are more La Niña like.

The tropical North Atlantic JJA SSTs are warmer in the MIS-13 experiment (Fig. 3f). This could be related to the warm anomaly in the far eastern Pacific. Curtis and Hastenrath (1995), Enfield and Mayer (1997), Klein (1999), and Hastenrath (2000) have all shown evidence of a link between the two regions. They could be coupled through changes in the Hadley and Walker circulations or the Pacific North American pattern (Wallace and Gutzler 1981). These circulations can act as a "bridge" coupling the two ocean basins.

The vertical wind along equator shows the reorganization of the Walker circulation in July (Fig. 6b). The updrafts are increased over the positive SST anomalies at $\sim 60^{\circ}-90^{\circ} \mathrm{E}$ and $\sim 80^{\circ}-110^{\circ} \mathrm{W}$. At the same time, there is an increase in the descent over the colder SSTs of the western Pacific at $120^{\circ} \mathrm{E}-180^{\circ}$. The two new action centers (at $\sim 80^{\circ} \mathrm{E}$ and $\sim 100^{\circ} \mathrm{W}$ ) correspond to the main convergence and convective activity with increased humidity stretching vertically to $350 \mathrm{mb}$ (Fig. 6c). The July surface winds in the tropical eastern Pacific are reversed in the MIS-13 experiment (Fig. 6d), bringing more warm moist air to Central America and feeding its summer monsoon (Fig. 2c). These changes to the Walker circulation facilitate communication from the equatorial Pacific to the Atlantic and could hence explain the SST changes seen in the equatorial Atlantic.

A change in SSTs of the tropical Pacific Ocean is thought to have the largest effects on the tropical parts of the EASM. However, for the unusually strong 1997/98 El Niño, a signal was found even in northern China; while there was extensive flooding in tropical parts of China, there was drought in the northern parts. The increase in SST in the east Pacific, in combination with the decrease in the west and a southward displacement of the west Pacific high, results in a southward shift in the 

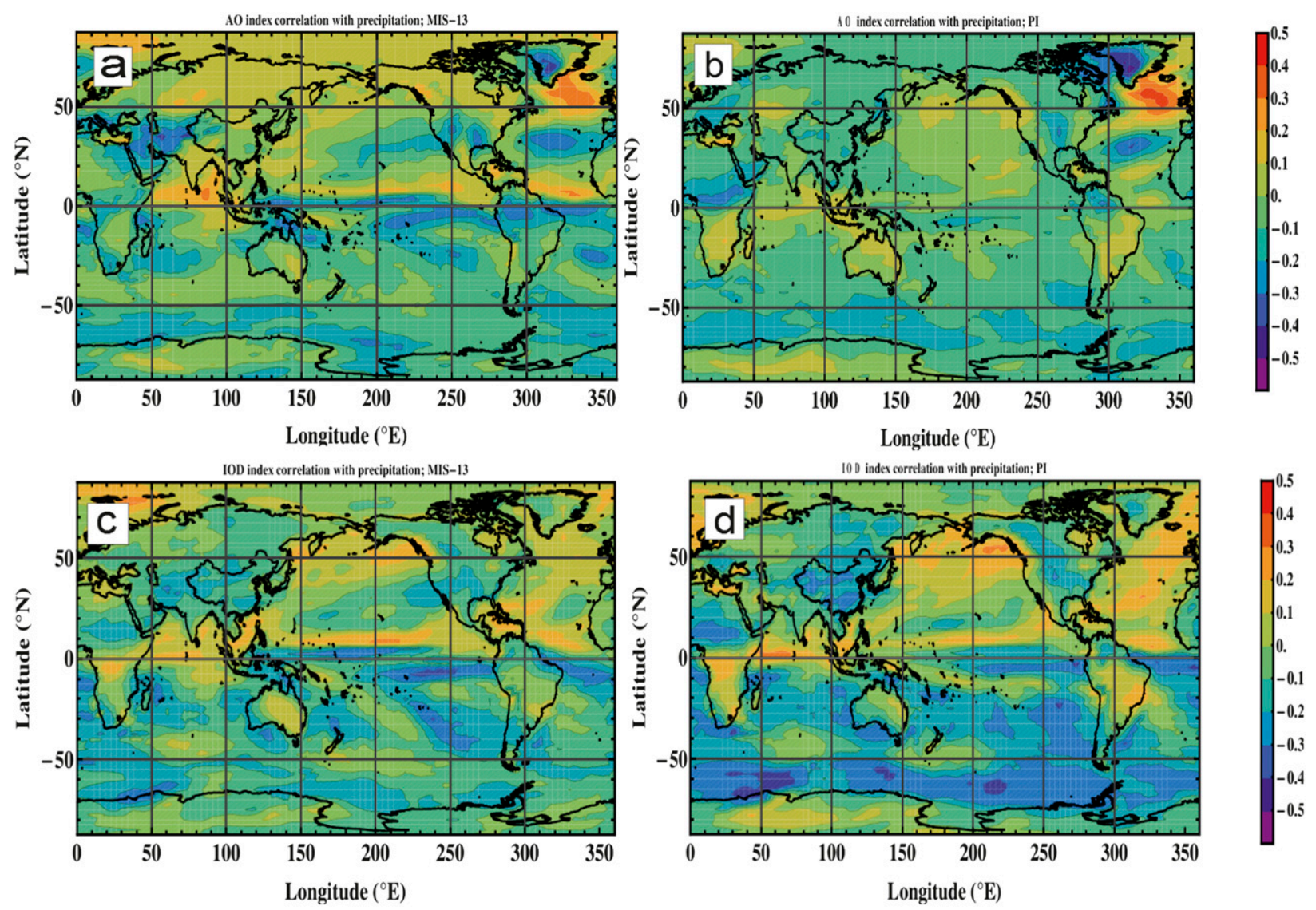

FIG. 5. Correlation between the AO index and annual precipitation rates in (a) the MIS-13 no-ice and (b) the PI simulations and the correlation between the IOD index and annual precipitation rates for (c) the MIS-13 no-ice and (d) the PI.

monsoon front. This MIS-13 case, however, is more complicated. The higher pressure over the North Pacific, as for a positive AO, leads to a stronger onshore moisture flux north of $20^{\circ} \mathrm{N}$ in China. This result is an increase in precipitation over the whole EASM region in this model experiment.

Circulation anomalies in the Philippine Sea tend to appear in conjunction with changes to the Pacific SSTs, affecting precipitation rates in East Asia (e.g., Wang et al. 2000; Watanabe and Jin 2002; Chou et al. 2009). The Philippine Sea anticyclonic anomaly (Fig. 7b) connects the climate of the tropical east Pacific and East Asia. The circulation anomaly is associated with changes in the Walker circulation, combined with the $1^{\circ}-2^{\circ} \mathrm{C}$ cooling of the west Pacific warm pool (Fig. 6a). The resulting positive horizontal moisture convergence contributes to the EASM enhancement in the southern parts.

\section{d. Indian Ocean dipole and the Indian monsoon}

The JJA SST in the Indian Ocean show indications of an Indian Ocean dipole positive phase; that is, there is a cold anomaly in eastern parts and a warm anomaly to the west of this (Fig. 6a). The positive SST anomaly lasts from July to November. The IOD has been linked to tropical Pacific SSTs (Ashok et al. 2001). The increase in precipitation in the eastern Pacific (Fig. 2c) is an indication of the shift in the Walker circulation. The Walker cell is descending over the western Pacific where the precipitation is suppressed (Fig. 7a) and the SST lowered. The easterly winds across the Indian Ocean are strengthened (Fig. 7d) and there is a buildup of warmer waters to the west. This easterly wind strengthening phenomenon in the model is also seen in observational data from positive IOD events (Sundaram et al. 2010). There is an increase in cross-equatorial flow in the eastern Indian Ocean (Fig. 7d). Strong cross-equatorial moisture transport has been known to facilitate strong monsoon conditions in India (Krishnan 2009). The correlation between precipitation rates and the IOD index is shown in Figs. 5c and 5d for the MIS-13 no-ice and PI, respectively. The correlation is higher in the MIS-13 simulation over India. Additionally, the intensified zonal wind shear contributes to increasing the barotropic 
(a)
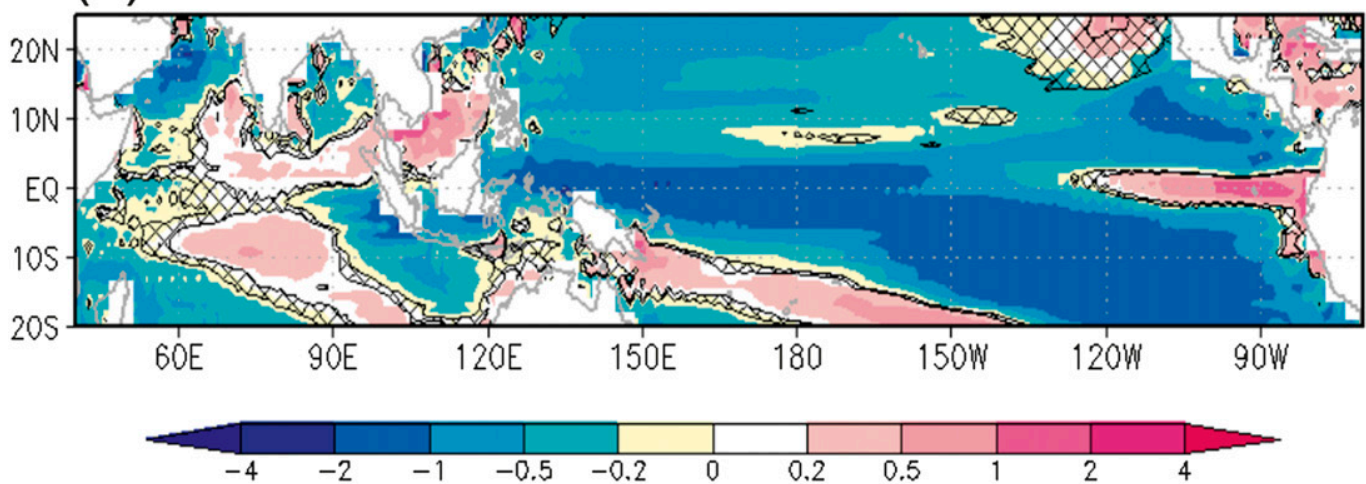

(b)

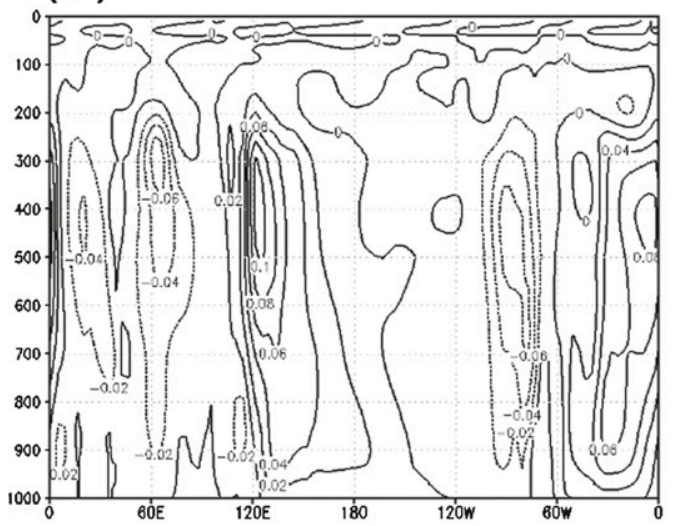

(c)

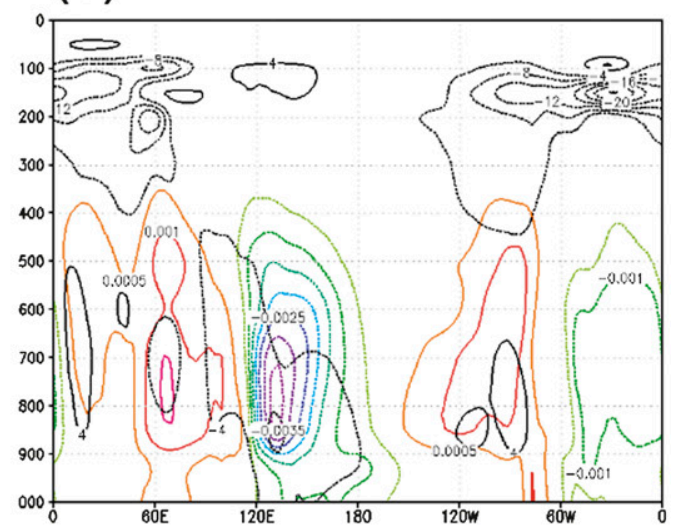

(d)

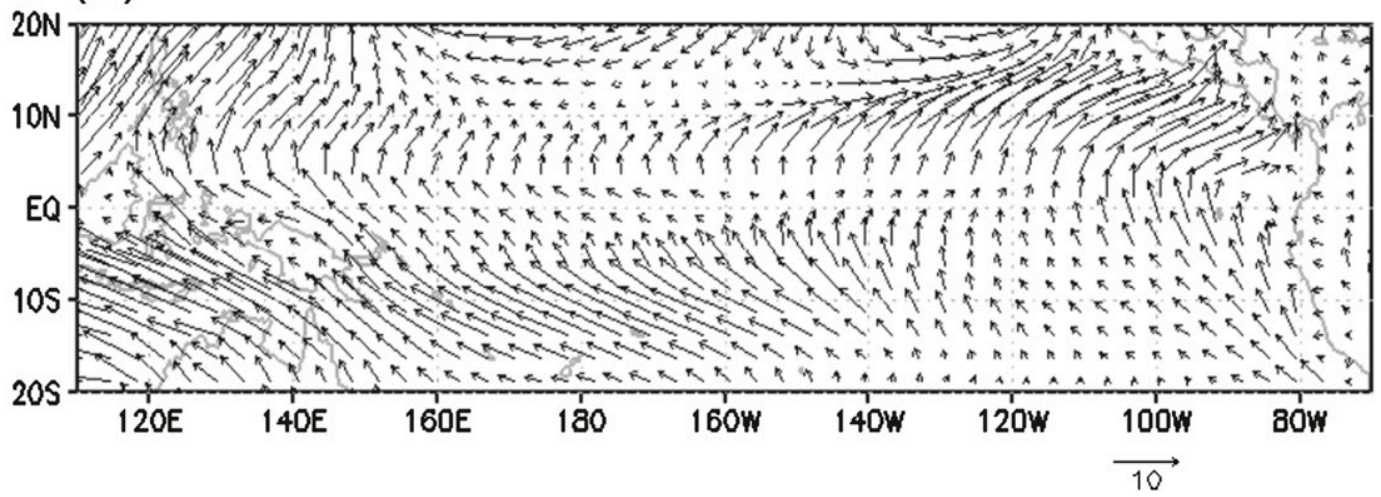

FIG. 6. Differences between the MIS-13 no-ice and PI experiments: (a) JJA SST (K; enlarged regional version of Fig. 2a), (b) the vertical profile in July along the equator of the vertical velocity differences ( $\mathrm{mPa} \mathrm{s}^{-1}$ ), (c) the specific humidity ( $\mathrm{kg} \mathrm{kg}^{-1}$; colored contours) and zonal wind differences ( $\mathrm{m} \mathrm{s}^{-1}$; black contours), and (d) the surface wind differences. Areas outside of the black hatching indicate a level of confidence higher than $95 \%$.

instability potential, which again is favorable for convective activity.

The two positive geopotential height anomalies in the Indian Ocean (Fig. 7b), one north and one south of the equator, tend to trigger and drive positive IOD-like events through their combined transport of warm surface waters to the western Indian Ocean.
The positive phase of the IOD has been known to increase the precipitation in the western Indian Ocean, North Africa, and northern India, while causing a warming of the air off the coast of Japan (Ashok et al. 2001; Saji et al. 1999). Similar features are identified in the MIS-13 no-ice HadCM3 experiment. The JJA geopotential height differences at $500 \mathrm{mb}$ show a heightening of $2 \mathrm{~m}$ over the 
(a)

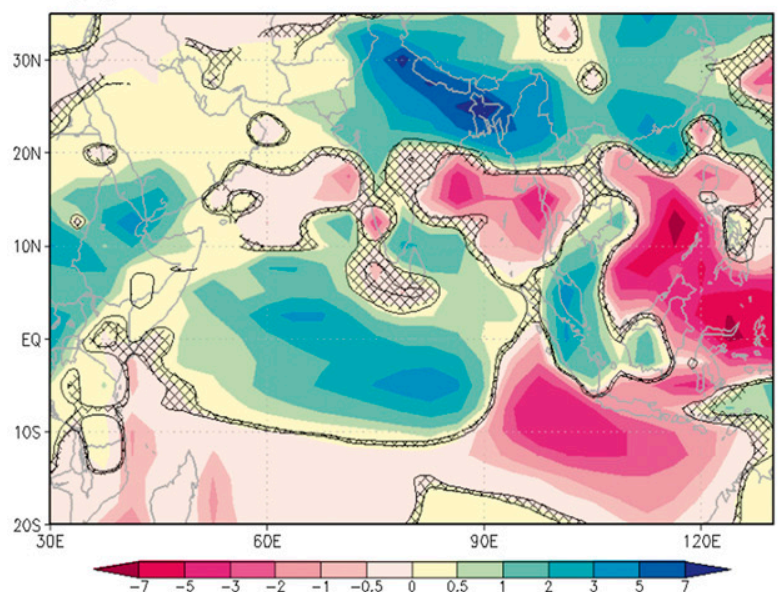

(c)

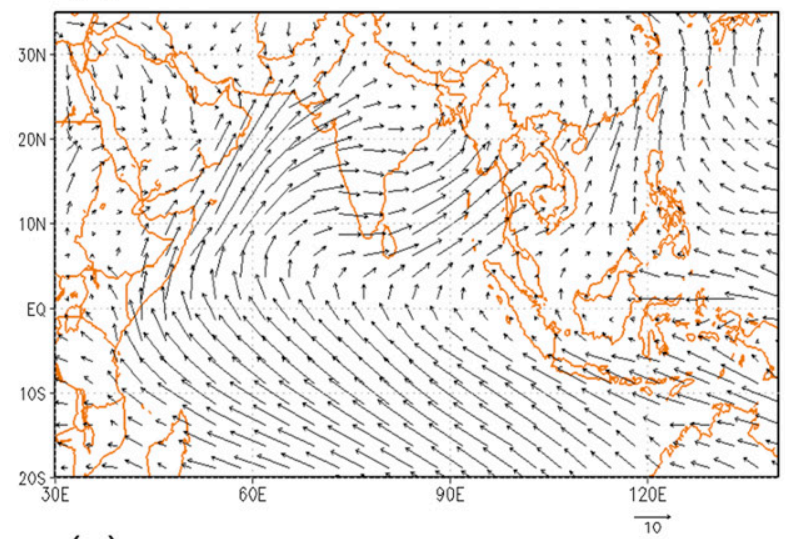

(e)

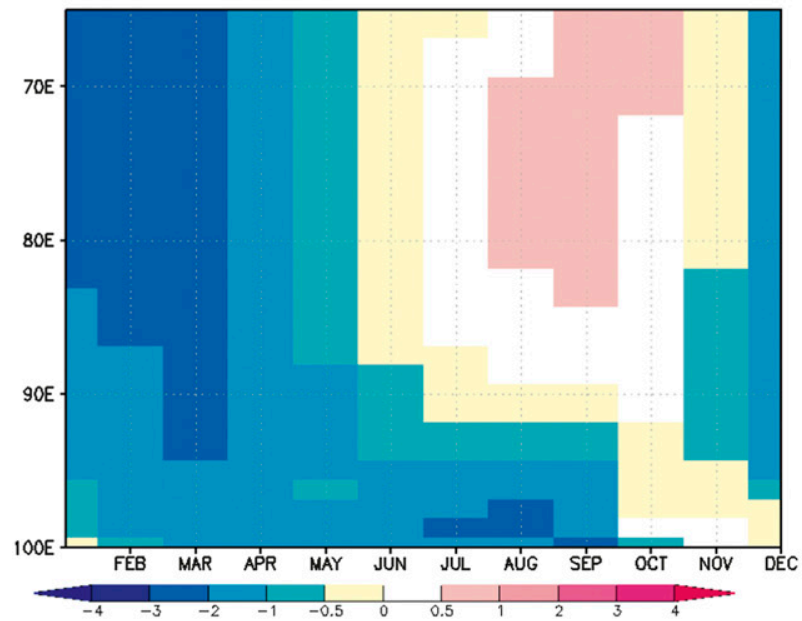

cold IOD-like anomaly (Fig. 7b). There is also a positive anomaly in the Bay of Bengal and Philippine Sea. The negative anomalies correspond to the regions of increased precipitation, that is, northern India, the western Indian Ocean, and North Africa. (b)

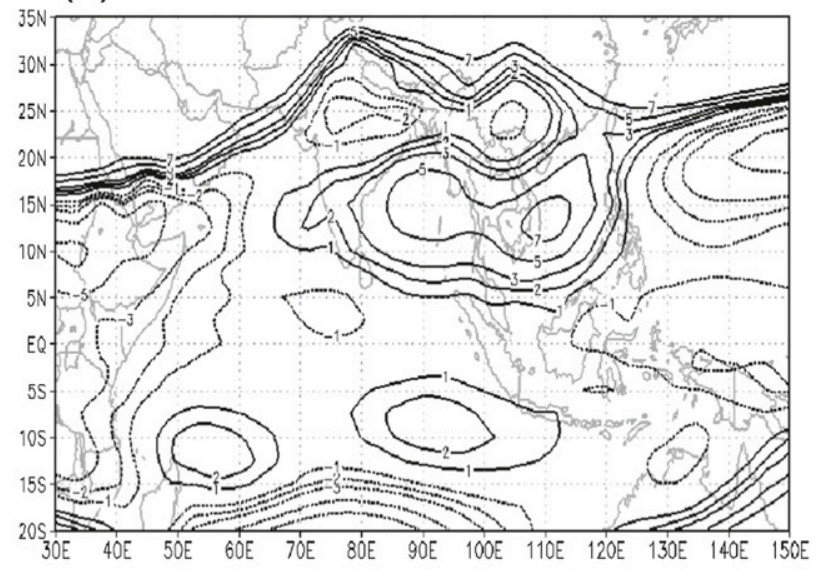

(d)

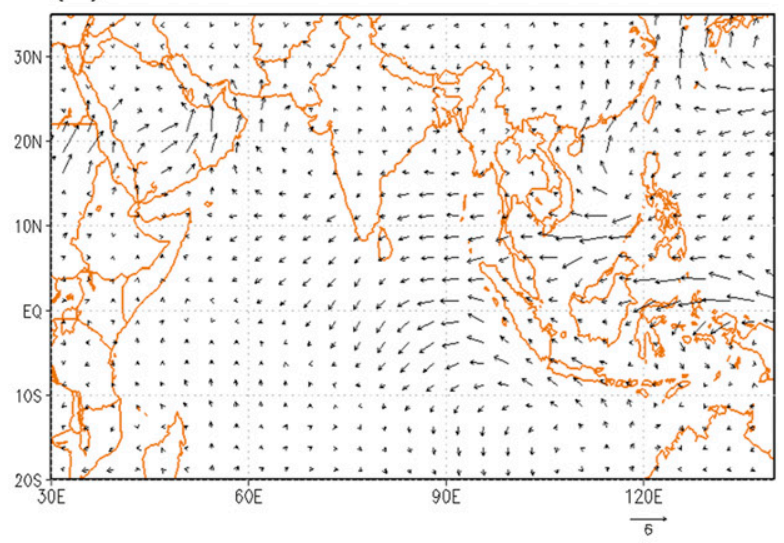

FIG. 7. (a) The JJA precipitation rate differences between MIS13 no-ice and PI (mm day ${ }^{-1}$; enlarged regional version of Fig. 2c), (b) the JJA geopotential height differences (m) at $500 \mathrm{hPa}$, (c) the JJA surface winds of MIS-13 no-ice, (d) the surface wind differences $\left(\mathrm{m} \mathrm{s}^{-1}\right)$ between MIS-13 no-ice and PI, and (e) the monthly evolution of the Indian Ocean SST differences.
The three teleconnection phenomena seen in this MIS-13 no-ice experiment are likely linked. That is, the El Niño-like SSTs in the Pacific could be correlated to the positive IOD-like condition, which has been linked to changes in the atmospheric conditions over the 
Pacific-North America region. The enhanced convection in the Indian Ocean and a reduction in the west Pacific initiate changes in North America (Franzke et al. 2011), impacting the AO conditions. Also, the reorganization of the Walker cell in the Pacific induces an atmospheric bridge to the Atlantic, possibly affecting the AO.

\section{The ice sheet impacts on the MIS-13 climate, in particular the East Asian summer monsoon}

To evaluate the impacts of the added ice sheets over North America and west Eurasia, the MIS-13 experiment with these two ice sheets, including the MIS-13 GHG and insolation values, is compared to the MIS-13 experiment with GHG and astronomical forcing only $(\exp 3-\exp 2)$. The presence of ice sheets can reduce the land-sea thermal contrast and thus weaken monsoon circulations (e.g., Keshavamurty and Sankar Rao 1992). Hence, first we evaluate the impacts on the East Asian summer monsoon.

The JJA precipitation rate differences between the MIS-13 ice and MIS-13 no-ice experiments (Fig. 8a) reveal that the ice sheets indeed contribute to intensify the EASM. This rather counterintuitive phenomenon was first detected in LOVECLIM by Yin et al. (2008) and later also in ARPEGE (Muri et al. 2011). There is a $0.3-1.5 \mathrm{~mm} \mathrm{day}^{-1}$ increase in northeastern, central, and southeastern China, stretching into the South China and Philippine Sea, with an increase also seen in the Amur region of Eurasia. It is dryer over Japan, however. This suppression of the baiu precipitation is attributed to an anticyclonic anomaly (Figs. 8c,e) centered over the northern island of Japan, induced by the ice sheets. This high pressure anomaly leads to a $0.3-1.5 \mathrm{~mm}$ day $^{-1}$ drying over Japan and Korea. On the other hand, it acts to increase the mei-yu rainfall, as the high is setting up an onshore flow onto the Chinese mainland from the North Pacific (Fig. 8c). The low-level winds pass over the warm SST of the west Pacific, picking up moisture, then into eastern China feeding the precipitation in the MIS-13 ice run. The JJA omega differences ( $\mathrm{Pa} \mathrm{s}^{-1}$; the vertical wind velocity, negative values indicate ascent) show how the regional precipitation decrease over Japan and Korea correspond to areas of reduced omega, while the updraft is increased over China (Fig. 7a).

The baiu precipitation is also suppressed by the ice sheets in the LOVECLIM experiment (Yin et al. 2008) and the magnitudes are comparable to the HadCM3; for example, in the Japan Sea there is a $0.3-1.2 \mathrm{~mm} \mathrm{day}^{-1}$ precipitation rate reduction. At the same time, the mei-yu front is enhanced in both models with a $0.1-1.3 \mathrm{~mm} \mathrm{day}^{-1}$ increase in LOVECLIM and $0.3-1.5 \mathrm{~mm} \mathrm{day}^{-1}$ increase in HadCM3. Though the spatial distribution differs somewhat between the models, the mechanisms behind the changes remain the same, proving the robustness of the results found in Yin et al. (2008). Some of the differences include a larger area of drying centered over the Sea of Japan in LOVECLIM (Fig. 8b), while the area of precipitation increase is larger in HadCM3. The surface wind patterns (Figs. 8c,d) are also within relative agreement between LOVECLIM and HadCM3, though the magnitude of change is larger in $\mathrm{HadCM} 3$, possibly explaining the higher precipitation increase by the mei-yu front. Furthermore, the discrepancies result from the differences in complexity, physical parameterization, and both horizontal and vertical resolution between the two models.

The positive geopotential height anomaly over north Japan, which is responsible for the precipitation increase over China, is part of a wavelike pattern. This starts on the west side of the west Eurasian ice sheet and ends over the northwest Pacific; that is, it propagates across Eurasia. There is an anomalous low centered over northeastern Europe, a high east of the Ural Mountains, a low over east Siberia, and a blocking high over north Japan (Fig. 8e). This wave pattern highly resembles the ice sheet response seen in the results from the LOVECLIM (Yin et al. 2008; Sundaram et al. 2012) and ARPEGE models (Muri et al. 2011). Only the positive anomaly over northern Japan is at a higher latitude and closer to land in HadCM3 and LOVECLIM, while the negative anomaly over east Siberia resides more northward in HadCM3 than the two other models. This Rossby wave has been demonstrated to be formed by the topography of the Eurasian ice sheet, and whether the Eurasian ice sheet can reinforce the EASM depends on the background insolation and its magnitude (Yin et al. 2009). The mountain torque from the ice sheets triggers angular momentum anomalies propagating in a westerly fashion. There is an anticyclonic flow anomaly around the ice sheets (Fig. 8c), and the increased northerly winds east of the ice promotes the drying seen on the lee side of the ice sheets (Fig. 8a).

The mean sea level pressure (MSLP) is heightened across the Arctic by as much as 3-4 hPa over the pole (Fig. 9b). It is lowered over the central North Atlantic by $1-1.5 \mathrm{hPa}$ and south of the ice sheets. The North Pacific high is stronger in the MIS-13 ice experiment, and the cell is expanded compared to the preindustrial. These synoptic-scale pressure changes, induced by the ice sheets, result in an absence of the positive AO-like phenomenon seen in the MIS-13 experiment without any added ice. The heightening of the pressure at high latitudes, in addition to the lowering of the surface pressure over midlatitudinal North America, the North Atlantic, and 
(a)

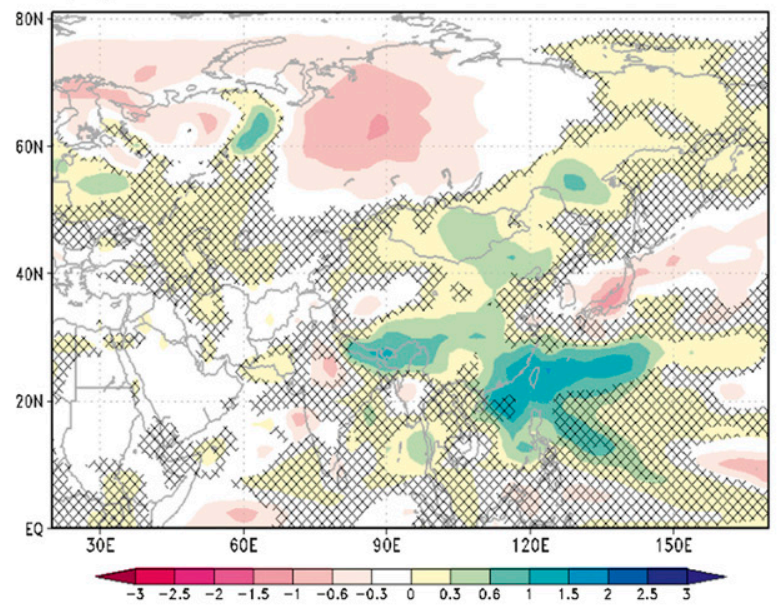

(c)

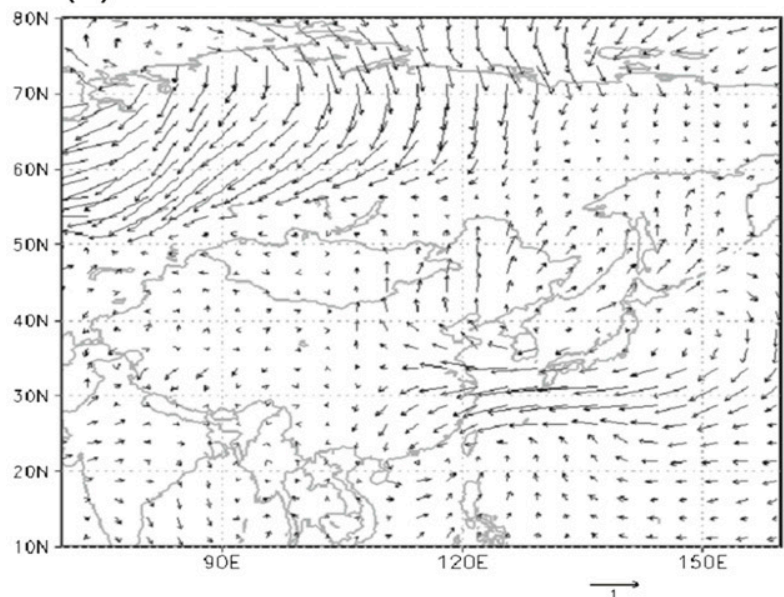

(e)

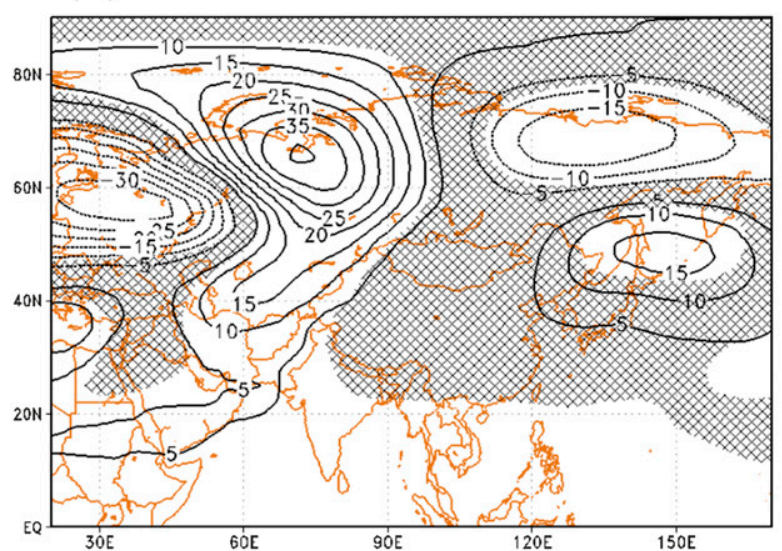

(b)

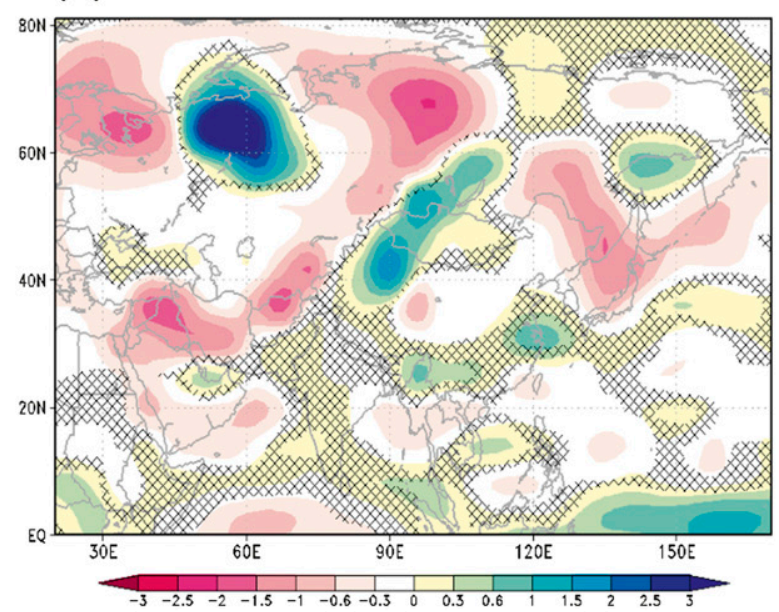

(d)

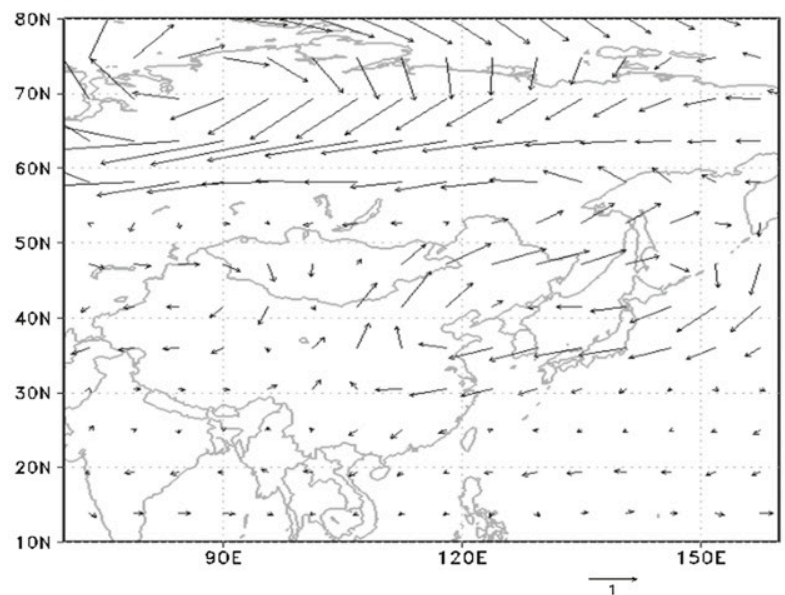

(f)

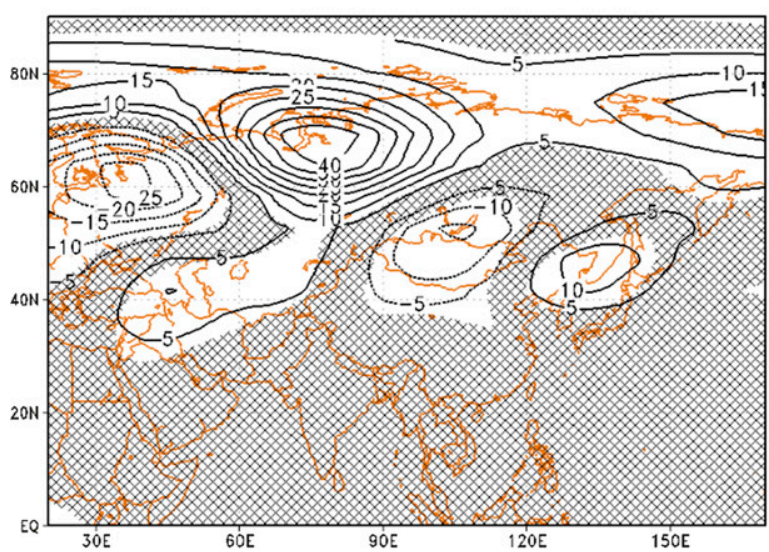

FIG. 8. The JJA differences between the MIS-13 ice and MIS-13 no-ice experiments for (left) HadCM3 and (right) LOVECLIM: (a),(b) precipitation rates $\left(\mathrm{mm} \mathrm{day}^{-1}\right),(\mathrm{c}),(\mathrm{d})$ surface winds, and (d),(e) the geopotential height $(\mathrm{m})$ differences at $500 \mathrm{hPa}$. Areas outside the black hatching indicate a level of confidence higher than $95 \%$. 
(a)

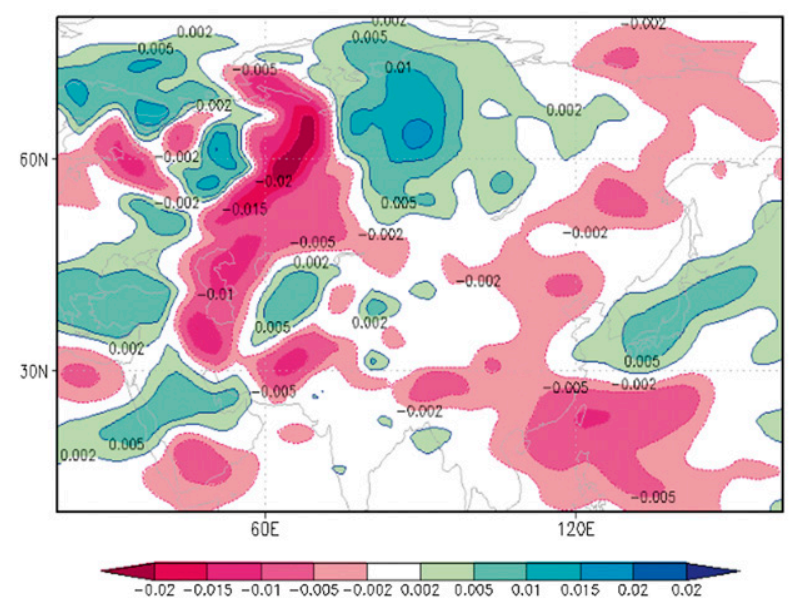

(b)

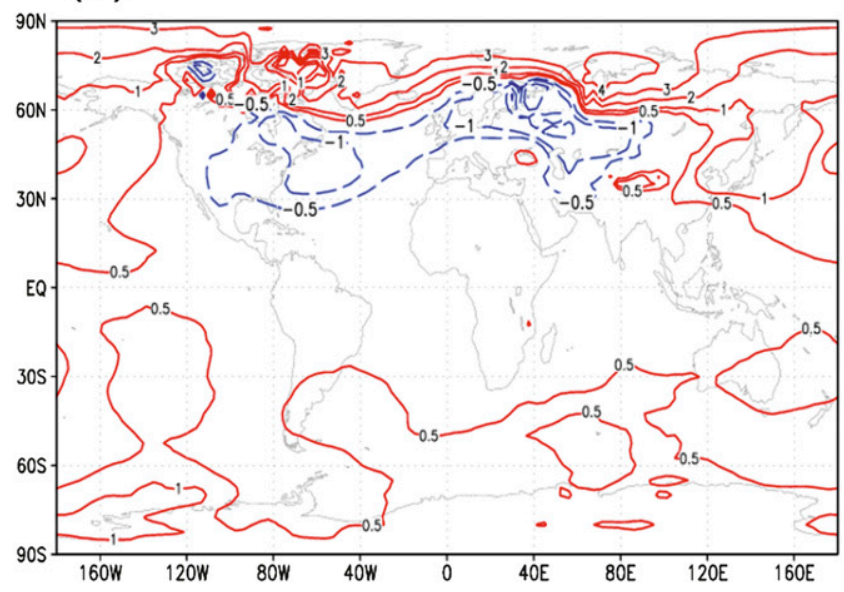

FIG. 9. (a) The vertical wind $\left(\Omega ; \mathrm{mPa} \mathrm{s}^{-1}\right)$ differences at $600 \mathrm{hPa}$ between the MIS-13 ice and MIS- 13 no-ice experiments $(\Omega$ positive downward) and (b) the JJA MSLP (mb) differences.

western Eurasia (Fig. 9b), indicates that the positive AO pattern is absent in the MIS-13 ice experiment. On the other hand, the positive IOD and El Niño conditions are still present in the MIS-13 ice experiment (Fig. 10e). The ice sheet impacts are hence not strong enough to overcome this signal in the MIS-13 climate.

The LOVECLIM SST differences between the MIS-13 ice and MIS-13 no-ice experiments show a warming of the North Pacific and an overall cooling of the Southern Ocean and the high-latitude North Atlantic (Muri et al. 2011). The HadCM3 displays a warming of the North Atlantic and cooling in the high-latitude Pacific and the Greenland/Barents Seas (Fig. 10d). The JJA SST warming signal in the midlatitude North Atlantic (Fig. 10d) could be due to the increase in the northward transport of warm waters by the Gulf Stream. This in combination with the easterly wind anomaly at mid-high latitudes could result in a pile up of warmer water here. The streamfunction of the oceanic upper layer shows a further increase in the Gulf Stream and Oyashio/Kuroshio in the North Pacific (Fig. 10e). It is further reduced by $0.2-0.5 \mathrm{~Sv}$ in the Southern Ocean where there is more sea ice (Fig. 10f).

The DJF sea ice concentration is higher in the northwestern rim of the Pacific and in the Barents and Greenland Seas, while it is lowered by as much as $15 \%$ in the Labrador Sea. JJA sees increased sea ice across the Arctic Ocean, though a decrease to the northwest of the North American ice sheet (Fig. 10f). As in LOVECLIM, the HadCM3 MIS-13 ice experiment experiences increased sea ice concentrations in the Southern Ocean throughout the year. The salinity is higher in the Arctic Ocean throughout the year, peaking in the vicinity of the ice sheets with a 2-3-psu increase. There is also a positive salinity anomaly in the midlatitudinal North Atlantic, while the water in the Labrador Sea is fresher. In JJA the waters are also fresher in the Barents Sea (Fig. 10b), possibly due to increased river runoff.

The meridional JJA SST gradient between the South and North Atlantic basins (Fig. 10c), of $1^{\circ}-2^{\circ} \mathrm{C}$ at tropical latitudes, results in increased convergence in the tropical North Atlantic. The air diverges aloft and crosses the equator before descending over the tropical South Atlantic. This gradient occurs when both insolation and ice sheet forcings are applied to the model. This way, the influence of the ice sheet can be transported to the Southern Hemisphere.

\section{Summary and conclusions}

We have examined aspects of the Marine Isotopic Stage 13 climate using a fully coupled AOGCM, evaluating the climatic response to insolation, $\mathrm{CO}_{2}$, and ice sheets. The LOVECLIM results of Yin et al. (2008), including the insolation-driven strong $\mathrm{NH}$ monsoons during MIS-13 and the ice sheet reinforced East Asian summer monsoon, are confirmed by the results presented here. The astronomical forcing for the time period leads to a substantial heating of the JJA continents, a deepening of the thermal lows, and an enhanced land-sea thermal contrast driving the strong monsoon. Furthermore, the inclusion of the NH ice sheets results in the triggering of wave activity and the establishment of an anticyclonic anomaly over Japan. This increases the onshore winds over China, strengthening the mei-yu frontal precipitation. Performing this set of experiments 
(a)

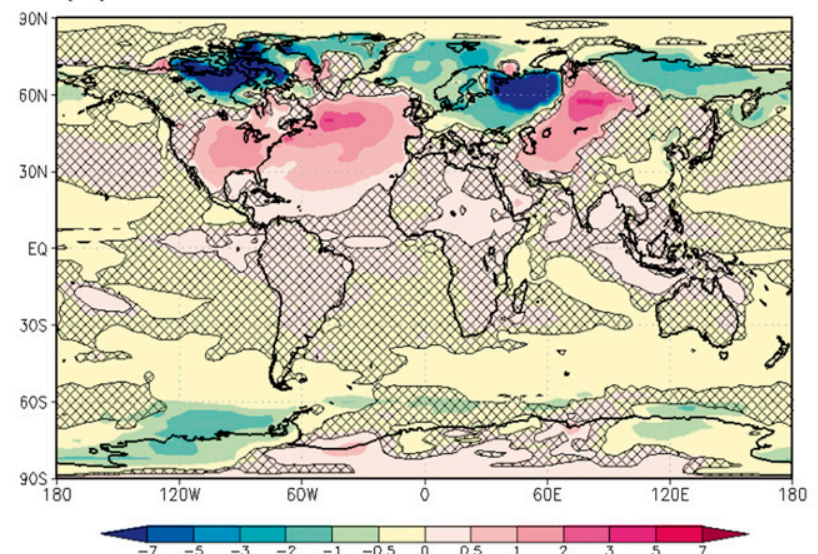

(c)

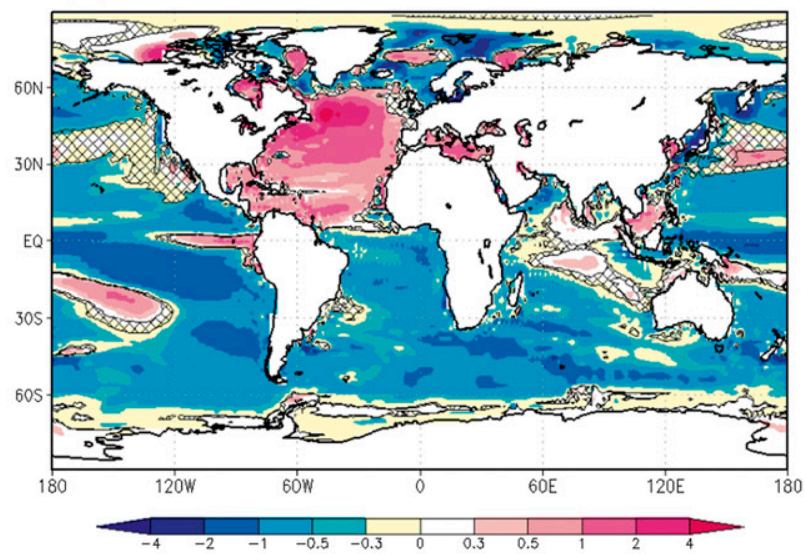

(e)

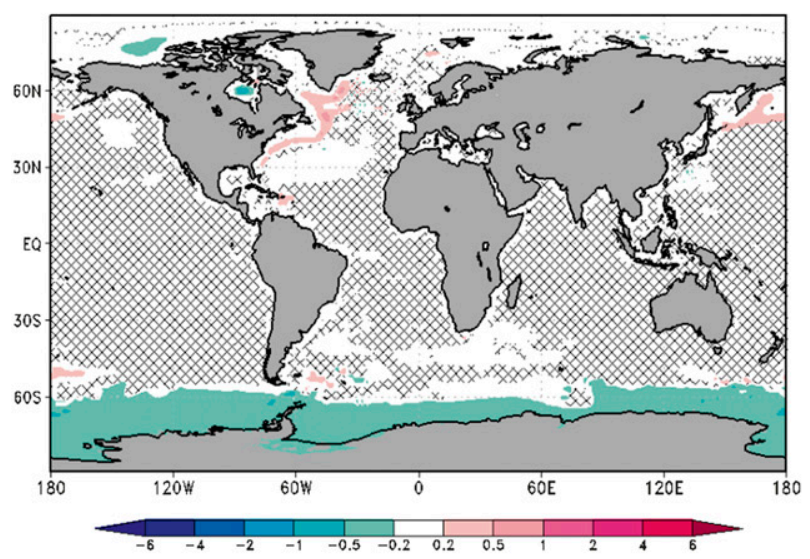

(b)

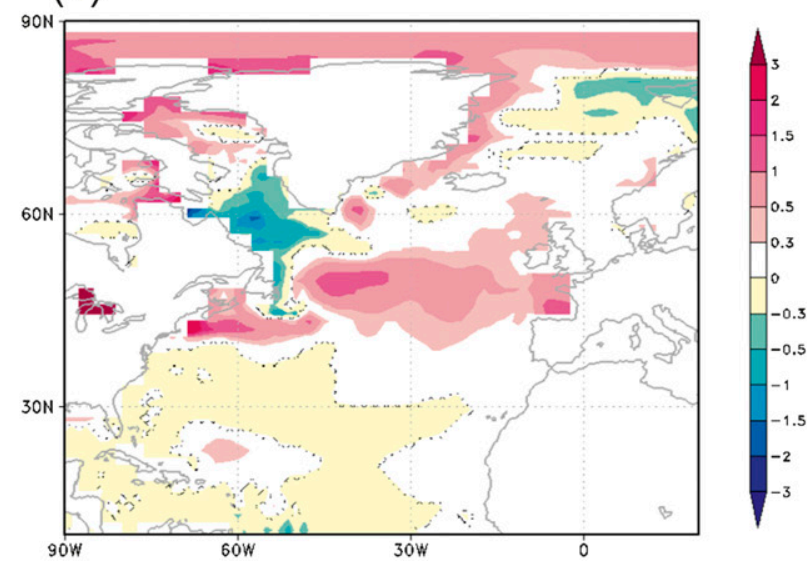

(d)

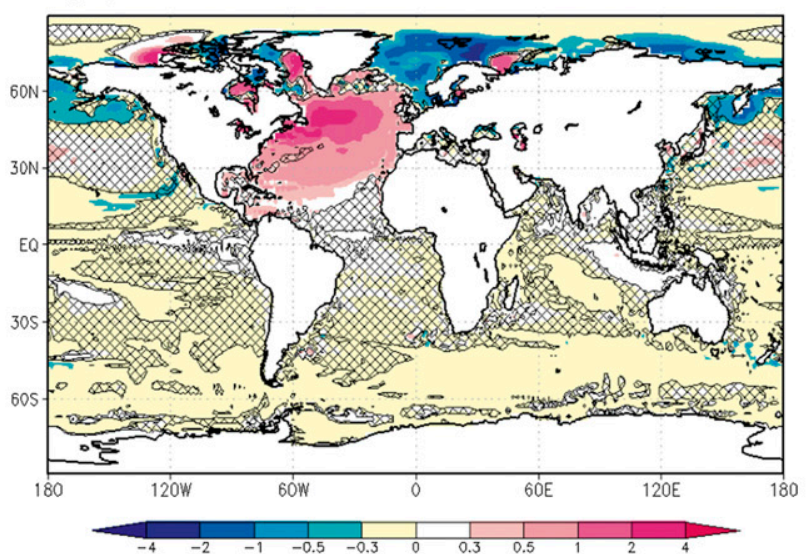

(f)

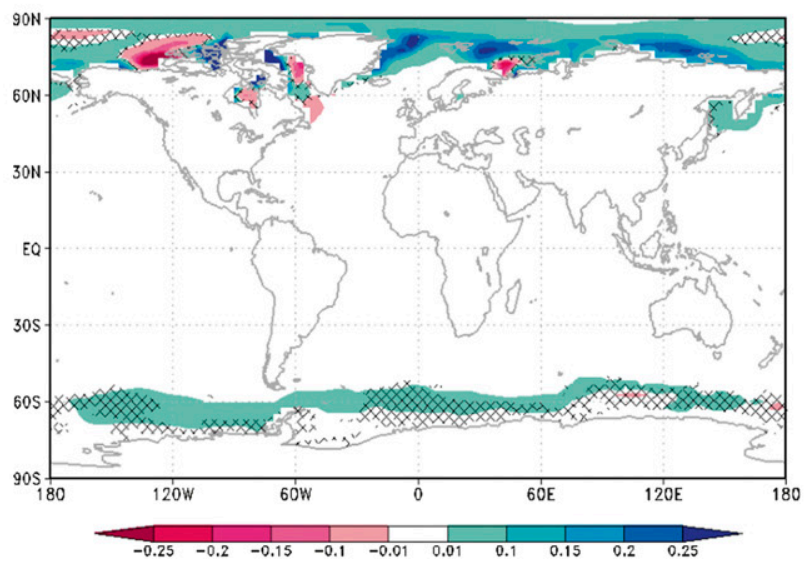

FIG. 10. The JJA (a) 1.5-m temperature differences between MIS-13 ice and no-ice and (b) JJA salinity differences (psu). The JJA SST differences (K) (c) between the MIS-13 ice and PI experiments and (d) between the MIS-13 ice and MIS-13 no-ice. (e) The annual-mean ocean surface streamfunction $\left(\mathrm{cm}^{3} \mathrm{~s}^{-1}\right)$ differences and (f) the JJA sea ice concentration differences (fraction). Nonhatched indicate a level of confidence higher than $95 \%$. 
with the AOGCM is a valuable validation of the LOVECLIM model, as it confirms that LOVECLIM is an expedient tool for broadscale climate investigations.

The HadCM3 presents a positive Arctic Oscillation mode in the MIS-13 no-ice experiment. In addition to this, the east-west gradient of the tropical Pacific SST decreased during the $\mathrm{NH}$ summer, causing rearrangement of the Walker circulation. A positive IOD-like pattern is developed in conjunction, owing to the changes in the Pacific trade winds.

The ENSO has the potential to affect the North Atlantic climate through an atmospheric bridge that links the Pacific to the Atlantic as a result of changes in the Walker circulation. These teleconnections are important modulators in present climate. It is also shown that current GCMs are, in fact, capable of representing these key features of the climate system.

The EMIC LOVECLIM has proven to be a resilient tool for climate simulations. More sophisticated AOGCMs do, however, provide more detailed and refined information. The results presented here enabled validation of a number of paleoobservations from the MIS-13, including the cold Antarctic, amplification of the seasonal temperature cycle, and the wetter and warmer monsoon areas. The inclusion of $\mathrm{NH}$ ice sheets contributes to amplifying the EASM precipitation. However, the configuration of the ice sheets during MIS-13 is still unknown and remains to be reconstructed from geological data or simulated with climate-ice sheet coupled models.

Acknowledgments. The EMIS project is funded by the ERC Advanced Grant 227348. H. Muri is supported by the EU 7th Framework Programme Project EuTRACE, Grant Agreement 306395. Q. Z. Yin is supported by the Belgian National Fund for Scientific Research (FRSFNRS). Thanks to S. Sundaram, N. Herold, and U. Singh for interesting and helpful discussions. Access to computer facilities was aided by a sponsorship from S. A. Electrabel, Belgium. The Met Office Hadley Center has allowed us to use the HadCM3 model and we are grateful to M. Crucifix for his contributions in making the model available at UCL. The authors would also like to thank the two anonymous reviewers for the helpful comments.

\section{REFERENCES}

Ambaum, M. H., B. J. Hoskins, and D. B. Stephenson, 2001: Arctic Oscillation or North Atlantic Oscillation? J. Climate, 14, 34953507.

Ashok, K., Z. Guan, and T. Yamagata, 2001: Impact of the Indian Ocean dipole on the relationship between the Indian monsoon rainfall and ENSO. Geophys. Res. Lett., 28, 4499-4502.

Bassinot, F. C., L. D. Labeyrie, E. Vincent, X. Quidelleur, N. J. Shackleton, and Y. Lancelot, 1994: The astronomical theory of climate and the age of the Brunhes-Matuyama magnetic reversal. Earth Planet. Sci. Lett., 126, 91-108.

Berger, A., 1978: Long-term variations of daily insolation and Quaternary climatic changes. J. Atmos. Sci., 35, 2362-2367.

Chen, F., J. Bloemendal, P. Zhang, and G. Liu, 1999: An 800 ky proxy record of climate from lake sediments of the Zoige Basin, eastern Tibetan Plateau. Palaeogeogr. Palaeoclimatol. Palaeoecol., 151, 307-320.

Chen, G. T., 1983: Observational aspects of the mei-yu phenomena in subtropical China. J. Meteor. Soc. Japan, 61, 306-312.

Cheng, H., and Coauthors, 2012: The climatic cyclicity in semiaridarid central Asia over the past 500,000 years. Geophys. Res. Lett., 39, L01705, doi:10.1029/2011GL050202.

Chou, C., L.-F. Huang, J.-Y. Tu, L. Tseng, and Y.-C. Hsueh, 2009: El Niño impacts on precipitation in the western North PacificEast Asian sector. J. Climate, 22, 239-257.

Collins, M., S. F. B. Tett, and C. Cooper, 2001: The internal climate variability of HadCM3, a version of the Hadley Centre coupled model without flux adjustments. Climate Dyn., 17, 61-81, doi:10.1007/s003820000094.

Cox, P., R. Betts, C. Bunton, R. Essery, P. R. Rowntree, and J. Smith, 1999: The impact of new land surface physics on the GCM simulation of climate and climate sensitivity. Climate Dyn., 15, 183-203.

Curtis, S., and Hastenrath, S., 1995: Forcing of anomalous sea surface temperature evolution in the tropical Atlantic during Pacific warm events. J. Geophys. Res., 100 (C8), 15 835-15847.

de Vernal, A., and C. Hillaire-Marcel, 2008: Natural variability of Greenland climate, vegetation, and ice volume during the past million years. Science, 320, 1622-1625.

Enfield, D. B., and D. A. Mayer, 1997: Tropical Atlantic sea surface temperature variability and its relation to El Niño-Southern Oscillation. J. Geophys. Res., 102 (C1), 929-945.

Franzke, C., S. B. Feldstein, and S. Lee, 2011: Synoptic analysis of the Pacific-North American teleconnection pattern. Quart. J. Roy. Meteor. Soc., 137, 329-346.

Gillett, N. P., M. R. Allen, R. E. McDonald, C. A. Senior, D. T. Shindell, and G. A. Schmidt, 2002: How linear is the Arctic Oscillation response to greenhouse gases? J. Geophys. Res., 107 (D3), doi:10.1029/2001JD000589.

Gordon, C., C. Cooper, C. A. Senior, H. Banks, J. M. Gregory, T. C. Johns, J. F. B. Mitchell, and R. A. Wood, 2000: The simulation of SST, sea ice extent and ocean heat transport in a version of the Hadley Centre coupled model without flux adjustment. Climate Dyn., 16, 147-168.

Gregory, D., G. Shutts, and J. Mitchell, 1998: A new gravity wave drag scheme incorporating anisotropic orography and low level wave breaking: Impact upon the climate of the UK Meteorological Office Unified Model. Quart. J. Roy. Meteor. Soc., 124, 463-493.

Guo, Z. T., and Coauthors, 1998: Climate extremes in Loess of China coupled with the strength of deep-water formation in the North Atlantic. Global Planet. Change, 18, 113-128.

- A. Berger, and Q. Yin, 2009: Strong asymmetry of hemispheric climates during MIS-13 inferred from correlating China Loess and Antarctica ice records. Climate Past, 5, 21-31.

Harris, S. E., and A. Mix, 1999: Pleistocene precipitation balance in the Amazon basin recorded in deep sea sediments. Quat. Res., 51, 14-26.

Hastenrath, S., 2000: Zonal circulations over the equatorial Indian Ocean. J. Climate, 13, 2746-2756.

Holmes, J., T. Atkinson, D. P. Darbyshire, D. Horne, J. Joordens, M. B. Roberts, K. J. Sinka, and J. E. Whittaker, 2010: Middle 
Pleistocene climate and hydrological environment at the Boxgrove hominin site (West Sussex, UK) from ostracod records. Quat. Sci. Rev., 29, 1515-1527.

Hoskins, B. J., and F.-F. Jin, 1991: The initial value problem for tropical disturbances to a baroclinic atmosphere. Quart. J. Roy. Meteor. Soc., 117, 299-318.

Hurrel, J. W., 1995: Decadal trends in the North Atlantic Oscillation regional temperature and precipitation. Science, 269, 676679.

— ciated with the North Atlantic Oscillation. Climatic Change, 36, 301-326.

Jouzel, J., and Coauthors, 2007: Orbital and millennial Antarctic climate variability over the past 800,000 years. Science, 317, 793-796.

Keshavamurty, R. N., and M. Sankar Rao, 1992: Monsoon variability on the glacial-interglacial time scale. The Physics of Monsoons, South Asia Books, 123-124.

Klein, S. A., 1999: Remote sea surface temperature variations during ENSO: Evidence for a tropical atmospheric bridge. J. Climate, 12, 917-932.

Krishnan, R., 2009: Significant influence of the boreal summer monsoon flow on the Indian Ocean response during dipole events. J. Climate, 22, 5611-5634.

Kukla, G., Z. S. An, J. L. Melice, J. Gavin, and J. L. Xiao, 1990: Magnetic susceptibility record of Chinese Loess. Trans. Roy. Soc. Edinburgh, 81, 263-288.

Lau, K. M., K. M. Kim, and S. Yang, 2000: Dynamical and boundary forcing characteristics of regional components of the Asian summer monsoon. J. Climate, 13, 2461-2482.

Locarnini, R. A., A. V. Mishonov, J. I. Antonov, T. P. Boyer, and H. E. Garcia, 2006: Temperature. Vol.1, World Ocean Atlas 2005, NOAA Atlas NESDIS 61, 50 pp.

Muri, H., A. Berger, Q. Yin, A. Voldoire, D. Salaz y Melia, and S. Sundaram, 2011: SST and ice sheet impacts on the MIS-13 climate. Climate Dyn., 39, 1739-1761, doi:10.1007/ s00382-011-1216-9.

Oh, J. H., W. Kwon, and S. B. Ryoo, 2007: Review of the researches on changma and future observational study (KORMEX). Adv. Atmos. Sci., 14, 207-222.

Pope, V. D., M. L. Gallani, P. R. Rowntree, and R. A. Stratton, 2000: The impact of new physical parametrizations in the Hadley Centre climate model: HadAM3. Climate Dyn., 16, 123-146.

Prokopenko, A. A., D. F. Williams, M. I. Kuzmin, E. B. Karabanov, G. K. Khursevich, and J. A. Peck, 2002: Muted climate variations in continental Siberia during the mid-Pleistocene epoch. Nature, 418, 65-68.

Rossignol-Strick, M., M. Paterne, F. C. Bassinot, K. Emeis, and G. J. de Lange, 1998: An unusual mid-Pleistocene monsoon period over Africa and Asia. Nature, 392, 269-272.

Saji, N. H., B. N. Goswami, P. Vinayachandran, and T. Yamagata, 1999: A dipole mode in the tropical Indian Ocean. Nature, 401, 360-364.

Sampe, T., and S. P. Xie, 2010: Large-scale dynamics of the meiyubaiu rainband: Environmental forcing by the westerly jet. J. Climate, 23, 113-134.
Spahni, R., and Coauthors, 2005: Atmospheric methane and nitrous oxide of the late Pleistocene from Antarctic ice cores. Science, 310, 1317-1321.

Spencer, H., R. T. Sutton, J. M. Slingo, M. Roberts, and E. Black, 2005: Indian Ocean climate and dipole variability in Hadley Centre coupled GCMs. J. Climate, 18, 2286-2307.

Sundaram, S., R. Krishnan, A. Dey, and P. Swapna, 2010: Dynamics of intensification of the boreal summer monsoon flow during IOD events. Meteor. Atmos. Phys., 107, 17-31.

- Q. Yin, A. Berger, and H. Muri, 2012: Impact of ice sheet induced North Atlantic Oscillation on East Asian summer monsoon during an interglacial 500,000 years ago. Climate Dyn., 39, 1093-1105, doi:10.1007/s00382-011-1213-z.

Thompson, D. W., and J. M. Wallace, 2000: Annular modes in the extratropical circulation. Part I: Month-to-month variability. J. Climate, 13, 1000-1016.

Trenberth, K. E., and D. A. Paolino, 1981: Characteristic patterns of variability of sea level pressure in the Northern Hemisphere. Mon. Wea. Rev., 109, 1169-1189.

—, G. W. Branstator, D. Karoly, A. Kumar, N.-C. Lau, and C. Ropelewski, 1998: Progress during TOGA in understanding and modelling global teleconnections associated with tropical sea surface temperatures. J. Geophys. Res., 103 (C7), 1429114324.

Walker, G. T., and E. W. Bliss, 1932: World weather V. Mem. Roy. Meteor. Soc., 4, 53-84.

Wallace, J. M., 2000: North Atlantic Oscillation/annular mode: Two paradigms-One phenomenon. Quart. J. Roy. Meteor. Soc., 126, 791-805.

_ , and D. S. Gutzler, 1981: Teleconnections in the geopotential height field during the Northern Hemisphere winter. Mon. Wea. Rev., 109, 784-812.

Wang, B., R. Wu, and X. Fu, 2000: Pacific-East Asia teleconnection: How does ENSO affect East Asian climate? J. Climate, 13, 1517-1536.

Watanabe, M., and F.-F. Jin, 2002: Role of Indian Ocean warming in the development of Philippine Sea anticyclone during ENSO. Geophys. Res. Lett., 29 (10), doi:10.1029/2001GL014318.

Yamagata, T., S. K. Behera, A. Rao, Z. Guan, K. Ashok, and N. H. Saji, 2003: Comments on dipoles, temperature gradient, and tropical climate anomalies. Bull. Amer. Meteor. Soc., 84, 14181422.

Yin, Q., and Z. T. Guo, 2006: Mid-Pleistocene vermiculated red soils in southern China as an indication of unusually strengthened East Asian monsoon. Chin. Sci. Bull., 51, 213-220.

_- and A. Berger, 2012: Individual contribution of insolation and $\mathrm{CO}_{2}$ to the interglacial climates of the past 800,000 years. Climate Dyn., 38, 709-724, doi:10.1007/s00382-011-1013-5.

- - , E. Driesschaert, H. Goosse, M. F. Loutre, and M. Crucifix, 2008: The Eurasian ice sheet reinforces the East Asian summer monsoon during the interglacial 500000 years ago. Climate Past, 4, 79-90.

,$- \ldots$, and M. Crucifix, 2009: Individual and combined effects of ice sheets and precession on MIS-13 climate. Climate Past, 5, 229-243. 